\title{
The use of trademarks in empirical research: Towards an integrated framework
}

\author{
SHUKHRAT NASIROV* \\ Centre for Enterprise and Innovation, De Montfort University
}

November 2018

\begin{abstract}
This paper represents an early attempt to develop an integrated framework linking empirical studies that make use of trademark statistics. Despite its youth, this field of scholarly activity has already accumulated a critical mass of papers that allow us to draw first general conclusions about the trademark lifecycle and its impact on organisational functioning. Based on a systematic review of 64 articles with some elements of empirical trademark analysis, five broad research areas have been identified, namely: the determinants of trademark deposits; the relationship between trademarks and innovation processes; the role of trademarks in differentiating product offerings; the strategic use of trademarks; and the impact of trademarks on firm performance. Within each category, a more detailed aggregation of articles has also been proposed. Overall, the analysis has shown that the performance-based perspective currently dominates the research landscape, with studies on trademark deposits and the trademark-innovation link to follow. At the same time, there is still little known about micro-foundations of a company's trademarking behaviour; the use of trademarks and other intellectual property rights in a complementary way and its effect on value transference; as well as the performance implications of differentiation strategy. This paper considers these and other findings to outline directions for future research.
\end{abstract}

KEYWORDS: intellectual property right; trademark; empirical study; literature review.

JEL CLASSIFICATION: D22, O34.

\footnotetext{
*Address for correspondence: Shukhrat Nasirov, De Montfort University, The Gateway, Leicester, LE1 9BH, UK. E-mail: Shukhrat.Nasirov@dmu.ac.uk.
} 


\section{INTRODUCTION}

Over the last several decades, the empirical analysis of intellectual property has been a thriving area, although the focus has almost exclusively been on patents and their impact on technological progress. At the same time, recent changes in the economic structure have led both academics and policymakers to revisit the toolbox of indicators they are currently using and look for new measures that would allow them to identify, monitor, and evaluate previously neglected processes and practices. A good example in this regard is the growing importance of services in the modern productive system and, thus, the need to have a more accurate account of innovation activities taking place there (see Gallouj and Weinstein, 1997; Hipp and Grupp, 2005). Since service sectors are usually associated with a weaker flow of R\&D investment and patent applications, if at all, conventional methods have a limited explanatory power and are likely to underestimate the extent of their innovativeness. Among the available alternatives, the choice has been made in favour of trademarks due to their widespread use across various industries, relevance to different organisational types, and close association with new product development (see Schmoch, 2003; Mendonça et al., 2004). In fact, this interest has been further reinforced by an increasing popularity of trademark protection in different countries and among a variety of organisations (see Figure 1.1).

Figure 1.1. The dynamics of trademark applications for the period 1985-2015
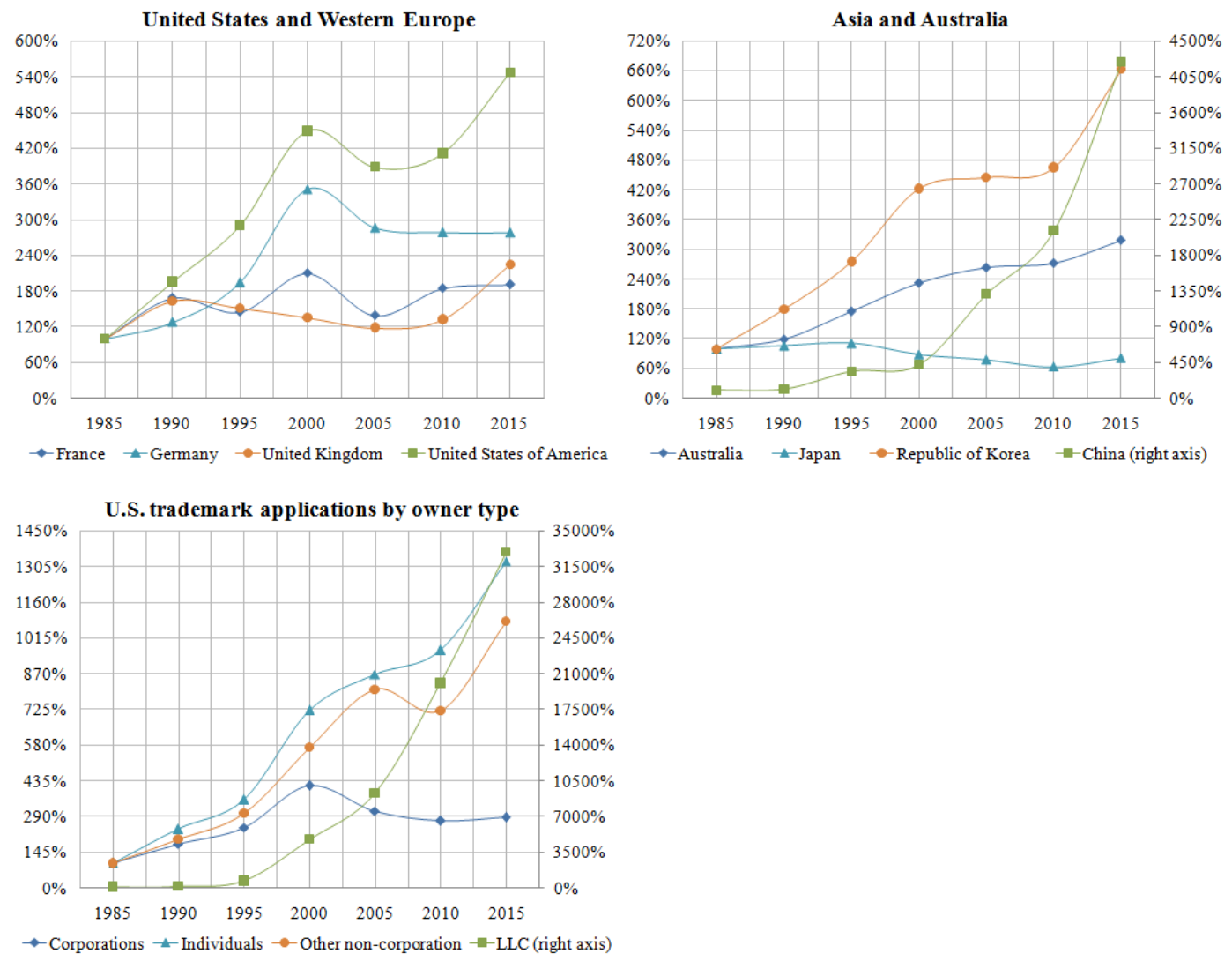

Sources: WIPO; USPTO. Note that: 1985 is set to $100 \%$; for China, 2015 is set to equal to 2014. 
Although the field of empirical trademark research is at its early stage of development, a critical mass of papers have already been accumulated that can be used to draw some initial conclusions about trademark activities and their effect on organisational functioning. As such, the purpose of this work is to identify the core empirical trademark literature, systematically review it, and design an integrated framework that brings together different research streams. This paper thus broadens the analysis presented in prior reviews (e.g., Mendonça et al., 2004; Schautschick and Greenhalgh, 2016) by looking at the fields that are adjacent to economics, including marketing and management. This approach enables us to offer a holistic perspective on trademark activities in organisations, including the stimulation of cross-disciplinary learning. Next, this work contributes to the existing reviews on intellectual property rights (e.g., Hanel, 2006; Candelin-Palmqvist et al., 2013) by placing specific focus on trademarks. Finally, along with reviewing the empirical literature on trademarks, this paper also summarises theoretical underpinnings behind each phenomenon associated with or reflected in trademark statistics, thereby making it easier to reconcile theoretical propositions and empirical observations.

To anticipate the results of our analysis, we have found that all empirical research on trademarks can be grouped into five broad categories, namely: the determinants of trademark filings; the role of trademarks in product differentiation; the relationship between trademarks and innovation activities; the strategic use of trademarks; and the influence of trademarking on organisational performance. To date, considerable attention has been paid to the evaluation of whether trademarks have an impact on firm value, productivity, and profitability. In line with the aforementioned need for new innovation measures, the association of trademarking with innovation processes has been carefully scrutinised as well. However, there are also areas that deserve further exploration. For example, little is known about intraorganisational factors governing trademark activities; studies that look at trademarking in developing countries are fairly rare; and more work should be done to address methodological inconsistencies to ensure a better comparability and validity of empirical results.

The reminder of the paper is organised as follows. Section 2 outlines the method used to identify the core trademark literature, as well as determines and explains the bibliographical patterns observed in the selected publications. Section 3 presents a detailed analysis of each paper and links it to the broader stream of research. Section 4 concludes with a discussion of implications for future studies. 


\section{THE IDENTIFICATION OF THE CORE LITERATURE}

\subsection{Methodology}

The principal objective of this work is to develop an integrated framework that brings together different streams of the empirical trademark literature. In order to do this, we first identified a broad sample of studies that examine trademark-related issues. Using the Business Source Premier database, we searched for such terms as "trademark" and "service mark" in the title, abstract, and key words of all indexed papers. We then limited the number of papers for review by excluding non-empirical research as well as articles published in law journals because it is highly unlikely that they would employ statistical analysis. ${ }^{2}$ Finally, we retained only those studies that were published as full-length articles in peer-reviewed journals in English. The above procedure left us with a superset of 566 papers explicitly referring to trademarks (see Table 2.1). Unlike previous reviews on a similar topic (e.g., Candelin-Palmqvist et al., 2012), we were unable to rely on a journal's impact factor or quality to narrow down the search because the empirical analysis of trademark data is still in its infancy, so even significant contributions can appear in relatively low ranked outlets.

Table 2.1. The selection of articles for review

\begin{tabular}{c|l|l|l|l}
\hline \hline $\begin{array}{c}\text { Stage } \\
\text { no. }\end{array}$ & \multicolumn{1}{|c|}{ Key word(s) } & Operation & Search field(s) & Result \\
\hline \hline 1 & $\begin{array}{l}\text { trade mark; trademark; service } \\
\text { mark }\end{array}$ & $\begin{array}{c}\text { Contain either of } \\
\text { these words }\end{array}$ & $\begin{array}{l}\text { TI: title } \\
\text { AB: abstract } \\
\text { SU: subject terms }\end{array}$ & 25,675 \\
\hline 2 & law; legal; legislation; tax & $\begin{array}{c}\text { Exclude either of } \\
\text { these words }\end{array}$ & $\begin{array}{l}\text { SO: publication } \\
\text { name }\end{array}$ & 24,126 \\
\hline 3 & $\begin{array}{l}\text { empirical; model; statistics; } \\
\text { survey }\end{array}$ & $\begin{array}{c}\text { Contain either of } \\
\text { these words }\end{array}$ & TX: all text & 4,035 \\
\hline 4 & academic journals & - & Source types & 586 \\
\hline 5 & English & - & Language & 566 \\
\hline \hline
\end{tabular}

Every article was subsequently reviewed to establish whether it met the inclusion criteria or not. First of all, we filtered out a significant number of papers that appeared in the original list because of the expression "United States Patent and Trademark Office" being present in the abstract or among the subject terms, whereas the papers per se were on topics

\footnotetext{
${ }^{2}$ A notable exception is Heald and Brauneis's (2011) study of trademark dilution.
} 
unrelated to trademark analysis. Some studies pointed to trademarks while talking about the concepts of dilution, infringement, and licensing, as well as assessing a company's brand strategy; since the absolute majority of them were not empirical, they were excluded from our review, too. With our initial search, we also retrieved several conceptual papers that focused primarily on classification issues, intellectual property management, or presented a new dataset (e.g., Hipp and Grupp, 2005; Conley et al., 2013) - these papers were dropped, although we still referred to them and elaborated on their ideas in corresponding sections. To make sure that all valuable contributions were accounted for, we supplemented the search results with articles identified in other review papers (e.g., Mendonça et al., 2004; Schautschick and Greenhalgh, 2016) and in the reference lists of the already selected empirical trademark studies. Overall, our screening generated a sample of 64 papers, which were used as a basis for this review. One of the major drawbacks of our approach, however, is that it largely misses out government reports, book chapters, working papers, and conference proceedings. This concern was addressed, to an extent, of course, by adding a table that briefly summarises some of such contributions, with the most critical ones being further mentioned in the review part.

\section{Figure 2.2. A summary of research streams in the empirical trademark literature}

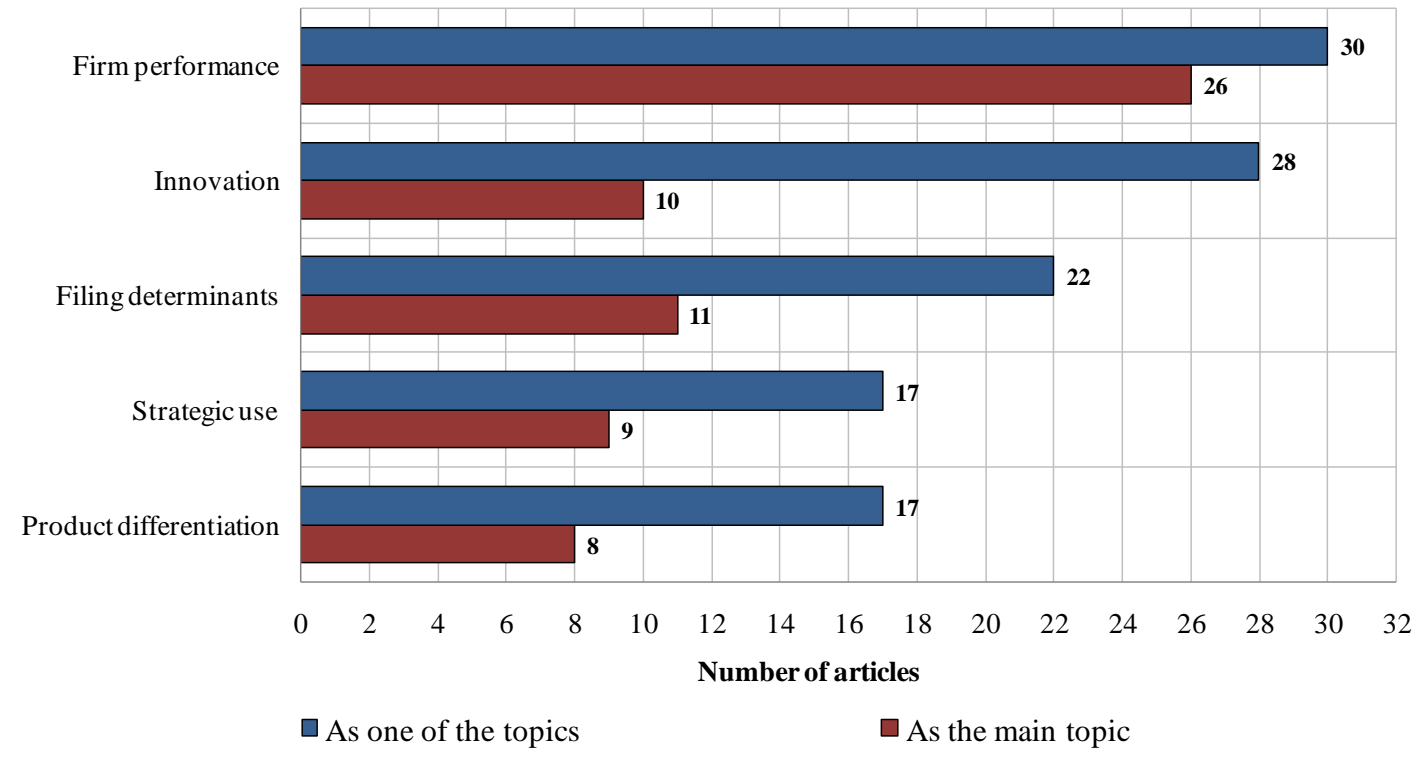

It needs to be noted that one paper can contribute to multiple research streams. Recognising that, we propose to look at two indicators: (i) blue bars show the number of articles in a field for which this field is one of the discussed topics; and (ii) red bars show the number of articles in a field for which this field is the main topic of discussion. Clearly, "firm performance" is likely to be a research topic on its own, while the remaining areas are mostly discussed along with some other topics.

We completed the literature identification stage by classifying each article into one or more groups, depending on the perspective taken towards trademarks. Overall, five major groups were identified, namely: 30 articles assess performance implications of trademarking; 
28 studies exploit the link between trademark and innovation activities; 22 papers attempt to identify the determinants of trademark deposits; 17 works explore the strategic use of trademarks; and in 17 publications, the authors refer to trademarks in the context of product differentiation (see Figure 2.2). Before proceeding to an in-depth analysis of each category, we should consider some stylised facts about publishing empirical trademark research.

\subsection{A descriptive analysis of the empirical trademark literature}

Figure 2.3 indicates that scholars had shown little interest in empirical trademark research before 2000s. Arguably, the earliest known study that utilised trademark statistics in a systematic way was the paper by Allegrezza and Guarda-Rauchs (1999), which attempted to identify the determinants of trademark filings and also explored a potential link between trademark activities and corporate innovation. Since then, there has been continuous growth in the use of trademark data that reached its maximum in 2012 when eight papers were published. There are many reasons behind this, including a significant effort directed by policymakers towards a better understanding of the impact that intellectual property has on economy and society (WIPO, 2013). The validity of this argument can be supported by looking at the recent proliferation of policy documents and reports touching upon trademark issues (see Table A.6). Trademark analysis also seems to be a useful tool for studying nontechnological innovation, such as business model innovation, marketing innovation, and innovation in services (Mendonça et al., 2004; Hipp and Grupp, 2005). Finally, the greater attractiveness of trademarks for empirical researchers can further be attributed to substantial improvements in the availability of trademark statistics achieved by removing certain barriers previously limiting access to this type of information (Graham et al., 2013).

Figure 2.3. The number of articles per publication year

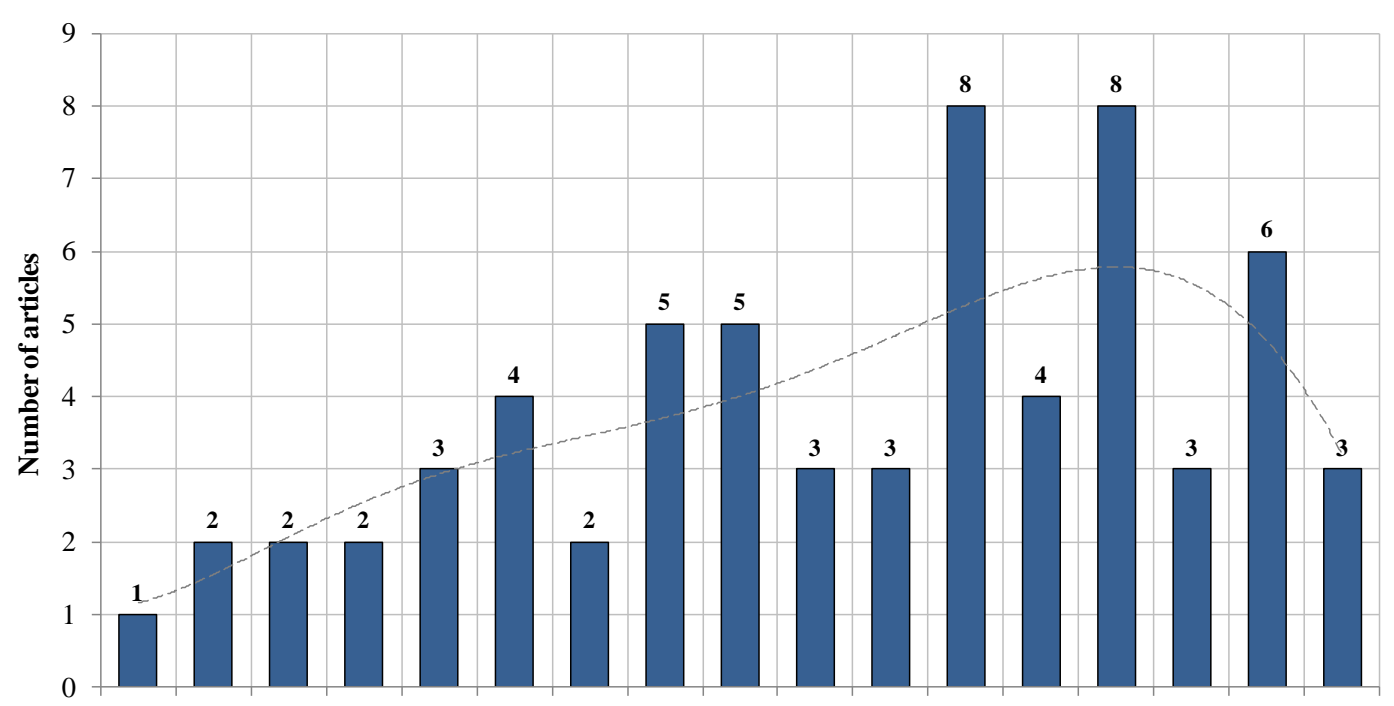

19992001200320042005200620072008200920102011201220132014201520162017

Publication year 
Evidently, Research Policy comes out as the most popular outlet for academic studies that make use of trademark data (see Figure 2.4). This journal was, in fact, among the first leading social science journals that pointed to the value of trademark statistics for improving our knowledge of corporate innovation and intellectual property strategies. Oxford Economic Papers is the second most popular outlet, although this result is mainly due to a special issue published in 2013 and entirely dedicated to innovation and intellectual property topics. Other named journals have a fairly equal percentage share, having two-tothree trademark-related papers accepted for publication over the last two decades. In total, 41 journals have published at least one empirical trademark paper - such journal diversity may reflect the broader appeal of trademark statistics, including its general applicability to research in economics, business, and management. Moreover, the recent tendency among top-tier outlets across all major fields to accept articles utilising trademark analysis is likely to indicate that this empirical perspective has gained academic credibility, which is necessary to ensure and maintain a high quality of research.

\section{Figure 2.4. The composition of articles by publishing journal}

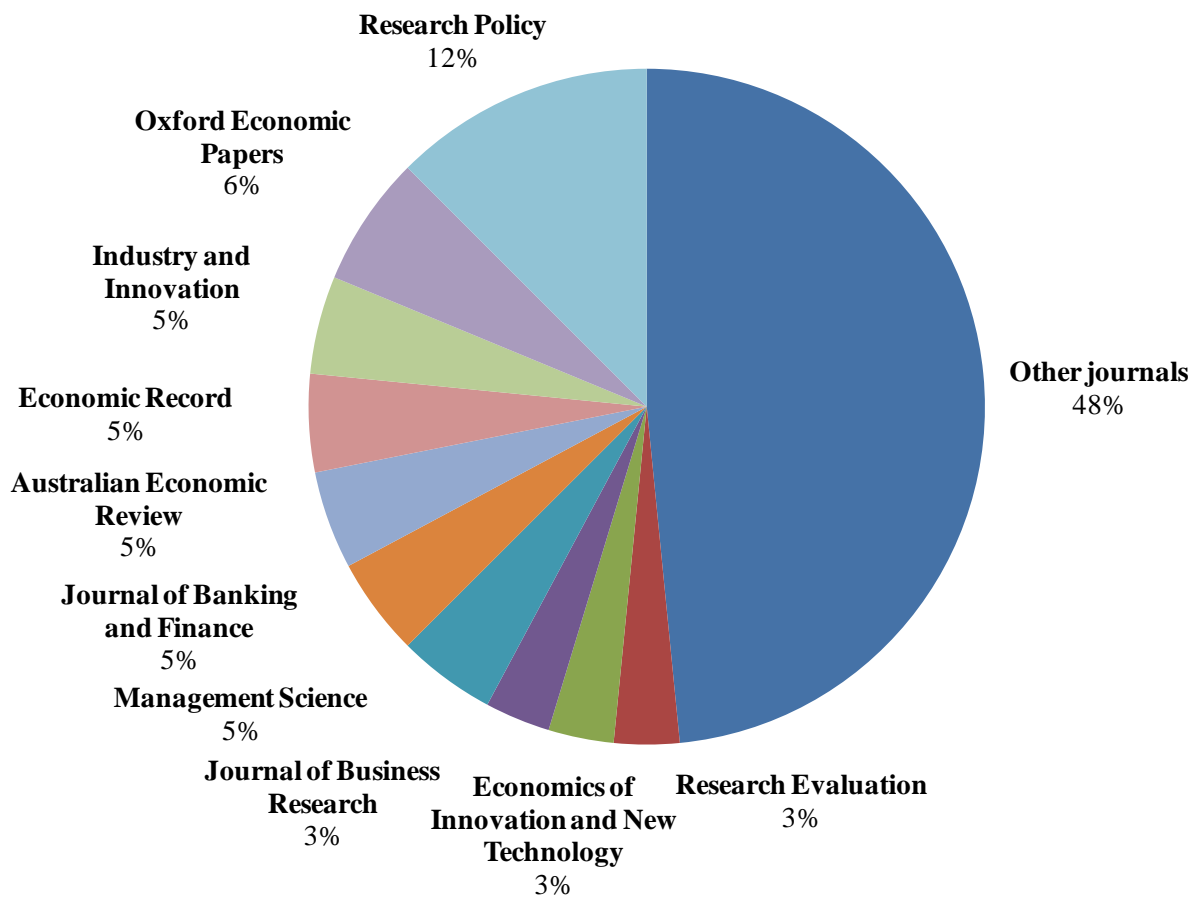

A number of useful insights can be drawn from the country emphasis in the selected publications. As it can be seen from Figure 2.5, the vast majority of the empirical trademark literature concentrates on developed economies, with studies confined to the U.S. institutional context currently dominating the research landscape. The fact that the U.S. has attracted so much scholarly attention is hardly surprising, given the size and importance of its market to the world economy, as well as the long and rich history of intellectual property 
protection in this country (Candelin-Palmqvist et al., 2012). It should further be noted that the geographical dimension warrants special consideration because of its close relationship with the way in which intellectual property systems are governed. Our analysis particularly suggests that most of these works revolve around countries with the common law system (e.g., the U.S., the U.K., and Australia), while continental law countries (e.g., Germany, Benelux states, and Spain) tend to have a fairly small share. Finally, cross-country comparisons are also popular in trademark analysis - they are often related to an attempt to identify the determinants of trademark filings in different countries and examine the role of trademark protection in international trade.

\section{Figure 2.5. The geographical scope of empirical trademark research}

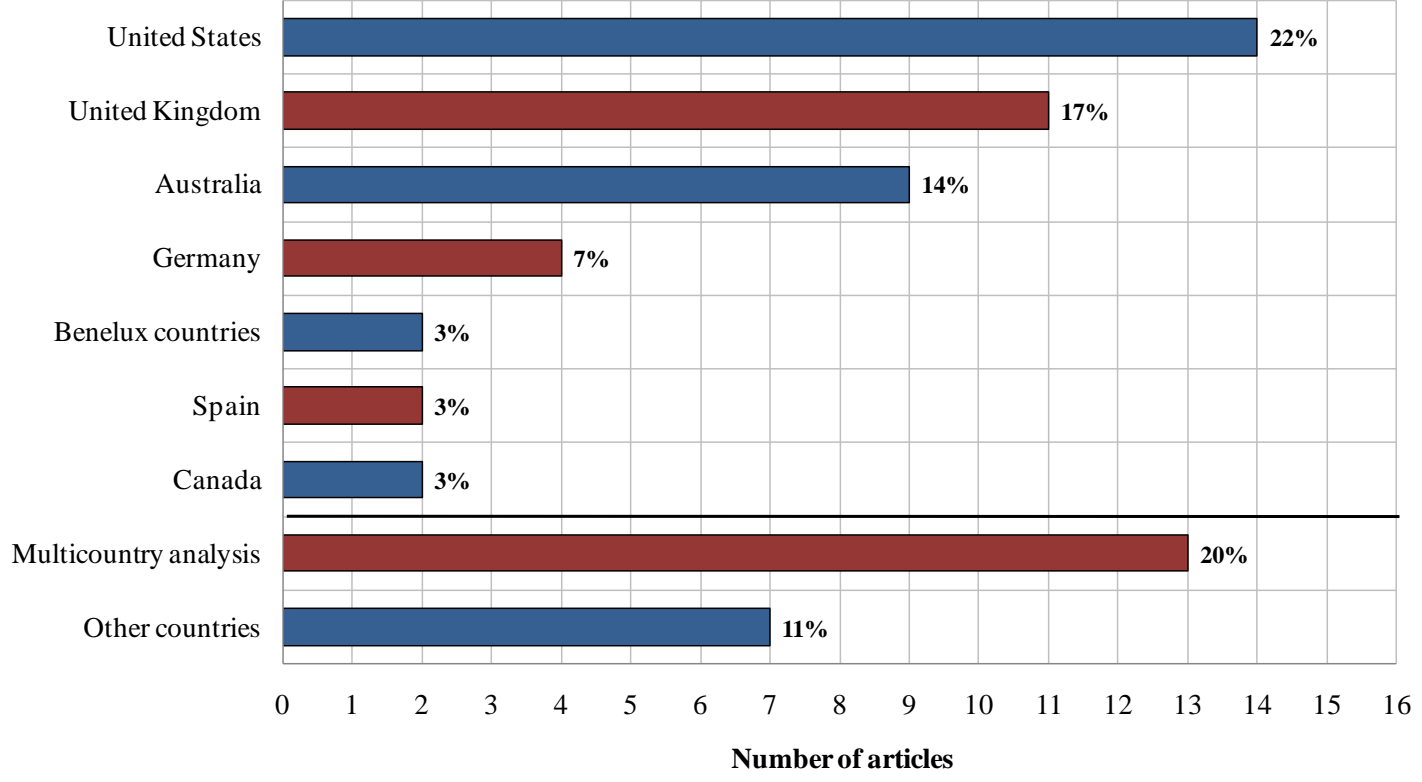

Figure 2.6 presents the key sources of trademark statistics. The results are largely consistent with what we have already observed for the geographical distribution of trademark studies, with the USPTO being the most popular provider of such information. Furthermore, there is a good reason to believe that the Office will maintain its leading position in the future, in part owing to the ongoing plan to continue disclosing intellectual property data in a form convenient for public access and academic research. ${ }^{3}$ Another important supplier of trademark statistics to mention is IP Australia - the Australian government agency responsible for administering intellectual property rights. In this case, we

\footnotetext{
${ }^{3}$ It should be noted that the USPTO is legally responsible for the dissemination of intellectual property information to the general public (35 U.S.C. §2). In order to keep up with this task, the Office has recently introduced a new research agenda that aims to unveil the relationship between intellectual property and economic growth. As such, for the first time they have disclosed detailed administrative data regarding trademark examination, registration, and assignment processes (see Graham et al., 2013; Marco et al., 2014).
} 
have a fine example of a productive collaboration between academia and the government sector because at least one of the authors of each paper that utilised trademark statistics from IP Australia pointed to their affiliation with the University of Melbourne, where the Agency established the Intellectual Property Research Institute of Australia in 2002. Finally, the need for cross-country comparisons has resulted in the use of the trademark statistics collected by supranational institutions, including the World Intellectual Property Organisation, the European Patent Office, and the Office for Harmonisation in the Internal Market. When taken together, their share in providing statistical information for empirical trademark research far exceeds $30 \%$.

\section{Figure 2.6. Major sources of trademark statistics}

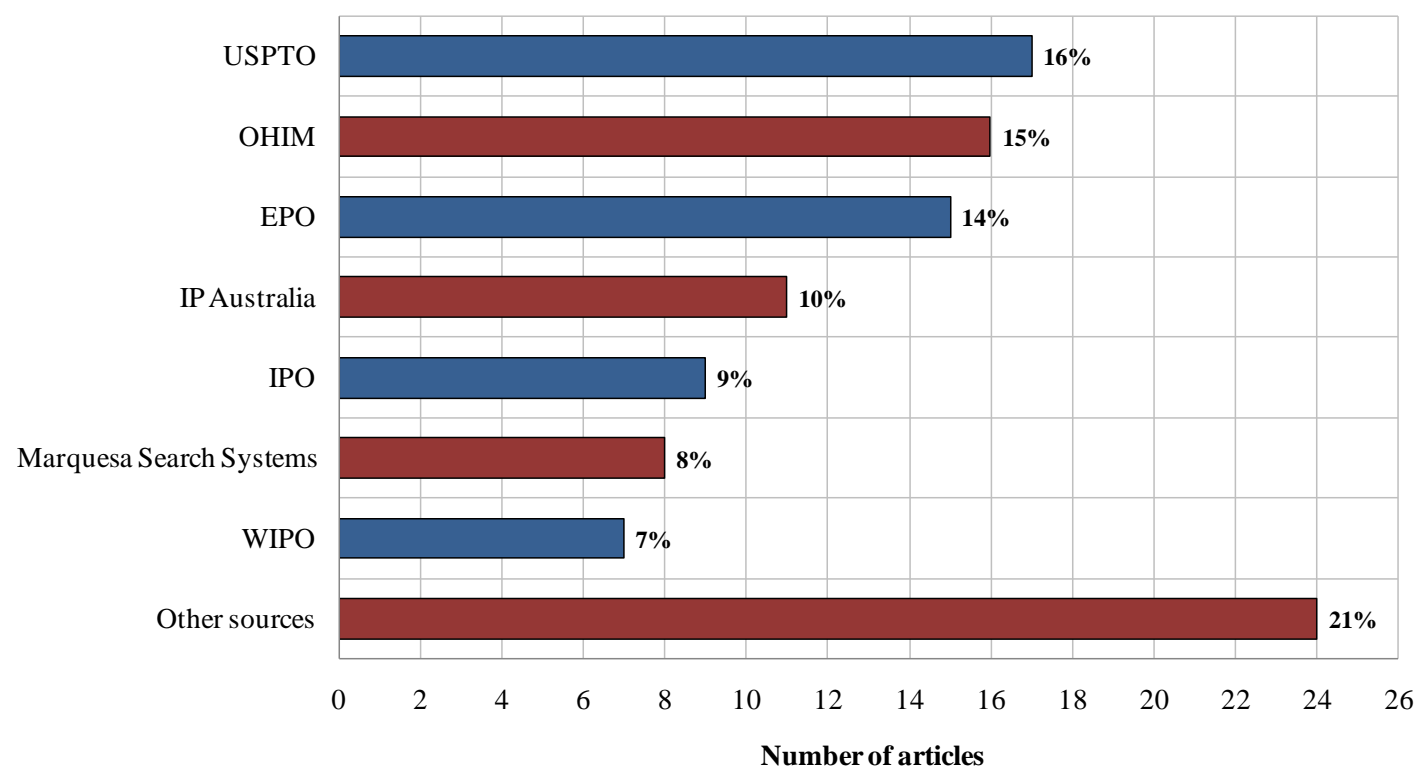

Note that since one article can draw on multiple sources of trademark information, the total number of articles here is higher than the total number of reviewed articles.

To date, the most cited article that employs trademark statistics is the work by Bosworth and Rogers (2001), which estimates the private returns from investing in intangible assets in Australia (see Table 2.2). Moreover, the performance perspective that includes such topics as market value, profitability, and firm survival, tends to be the most popular area in the empirical trademark literature, with six out of the top 10 publications addressing it in one or another way. Other highly cited articles make use of trademark statistics to capture corporate innovation and strategic activities. As for publishing journals, Research Policy clearly dominates the top 10 list, thus once again establishing itself as a major outlet for this type of work. And to conclude, we can also point to Australia as the most popular setting among the top cited papers; however, the time factor should be taken into account here because these are also one of the oldest papers in our sample. 
Table 2.2. Top 10 most cited articles that use trademark statistics

\begin{tabular}{|c|c|c|c|c|}
\hline $\begin{array}{l}\text { Number } \\
\text { of citations }\end{array}$ & Author(s) & Article name & Journal & Year \\
\hline 290 & Bosworth, D.; Rogers, M. & $\begin{array}{l}\text { Market value, R\&D and } \\
\text { intellectual property: An } \\
\text { empirical analysis of large } \\
\text { Australian firms } \\
\end{array}$ & $\begin{array}{l}\text { Economic } \\
\text { Record }\end{array}$ & 2001 \\
\hline 251 & $\begin{array}{l}\text { Mendonça, S.; Pereira, T.S.; } \\
\text { Godinho, M.M. }\end{array}$ & $\begin{array}{l}\text { Trademarks as an indicator of } \\
\text { innovation and industrial } \\
\text { change }\end{array}$ & $\begin{array}{l}\text { Research } \\
\text { Policy }\end{array}$ & 2004 \\
\hline 204 & Greenhalgh, C.; Rogers, M. & $\begin{array}{l}\text { The value of innovation: The } \\
\text { interaction of competition, } \\
\text { R\&D and IP }\end{array}$ & $\begin{array}{l}\text { Research } \\
\text { Policy }\end{array}$ & 2006 \\
\hline 202 & $\begin{array}{l}\text { Amara, N.; Landry, R.; } \\
\text { Traoré, N. }\end{array}$ & $\begin{array}{l}\text { Managing the protection of } \\
\text { innovations in knowledge- } \\
\text { intensive business services }\end{array}$ & $\begin{array}{l}\text { Research } \\
\text { Policy }\end{array}$ & 2008 \\
\hline 137 & Sandner, P.G.; Block, J. & $\begin{array}{l}\text { The market value of } R \& D \text {, } \\
\text { patents, and trademarks }\end{array}$ & $\begin{array}{l}\text { Research } \\
\text { Policy }\end{array}$ & 2011 \\
\hline 113 & $\begin{array}{l}\text { Krasnikov, A.; Mishra, S.; } \\
\text { Orozco, D. }\end{array}$ & $\begin{array}{l}\text { Evaluating the financial impact } \\
\text { of branding using trademarks: } \\
\text { A framework and empirical } \\
\text { evidence }\end{array}$ & $\begin{array}{l}\text { Journal of } \\
\text { Marketing }\end{array}$ & 2009 \\
\hline 110 & Schmoch, U. & $\begin{array}{l}\text { Service marks as novel } \\
\text { innovation indicator }\end{array}$ & $\begin{array}{l}\text { Research } \\
\text { Evaluation }\end{array}$ & 2003 \\
\hline 101 & Feeny, S.; Rogers, M. & $\begin{array}{l}\text { Innovation and performance: } \\
\text { Benchmarking Australian } \\
\text { firms }\end{array}$ & $\begin{array}{l}\text { Australian } \\
\text { Economic } \\
\text { Review }\end{array}$ & 2003 \\
\hline 101 & $\begin{array}{l}\text { Buddelmeyer, H.; Jensen, P.H.; } \\
\text { Webster, E. }\end{array}$ & $\begin{array}{l}\text { Innovation and the } \\
\text { determinants of company } \\
\text { survival }\end{array}$ & $\begin{array}{l}\text { Oxford } \\
\text { Economic } \\
\text { Papers }\end{array}$ & 2010 \\
\hline 96 & Semadeni, M.; Anderson, B.S. & $\begin{array}{l}\text { The follower's dilemma: } \\
\text { Innovation and imitation in the } \\
\text { professional services industry }\end{array}$ & $\begin{array}{l}\text { Academy of } \\
\text { Management } \\
\text { Journal }\end{array}$ & 2010 \\
\hline
\end{tabular}

The number of citations for each article was retrieved from Google Scholar on September 15, 2017. 


\section{A REVIEW OF EMPIRICAL TRADEMARK RESEARCH}

\subsection{The determinants of trademark deposits}

General background. In economic theory, a company's decision to file a trademark application is usually explained by referring to the cost-benefit analysis. That is, a trademark should be registered only if the expected value of its registration exceeds the opportunity cost of the registration procedure (Economides, 1988; Mendonça et al., 2004). However, empirical trademark research suggests that such a decision goes far beyond mere cost-benefit considerations and largely depends on the interaction between external and internal environments. External environment is determined by different forces acting outside the company and their influence on the company's adaptation process. Its structure is complex and consists of several interrelated layers, including the industries and region in which the company operates; it may also extend across national borders and multiple jurisdictions. A practical impact of external environment on the company's propensity to trademark is likely to manifest itself in substantial discrepancies in trademark deposits among economic sectors, countries, and agglomerations of states. As for internal environment, it denotes the composition of managerial, organisational, and work practices that affect organisational functioning. A detailed analysis of these practices aims at revealing critical dimensions along which companies, even from the same industry, may still differ with respect to trademark activities they pursue. For example, the availability of financial resources can impose a constraint on the intensity of trademark applications, whereas the internal policy to ensure full-fledged protection of intangible capital - facilitate them.

\section{The effect of external environment on trademark deposits}

Literature review. According to Baroncelli et al. (2005), the distribution of trademark ownership among countries is uneven and tends to be highly skewed towards companies from advanced, market-based economies, which altogether account for the great majority of trademark registrations. To explain these disparities, the authors suggest considering the link between brand reputation and trademarking behaviour. As the argument goes, companies from developing countries are much more constrained in the ability to export products to foreign markets because their brands have not gained enough recognition among potential customers, mainly owing to the lack of information regarding product quality, past business practices, and commercial performance. This eventually leads to a poor visibility of such companies in international trade, with a negative effect on the number of trademarks they have to first introduce and then formally protect. Developing countries, in turn, may impose discriminatory measures against overseas applicants to reduce the competitive pressure foreign producers put on domestic companies, especially when the 
quality of products manufactured by local companies is similar to that of outsiders (Baroncelli et al., 2007).

Mangàni (2006) extends the above findings by showing that recently, there has been a noticeable increase in the use of service marks. He argues that multiple factors can contribute to this dynamics, among which "[t]he structural change of economies, higher tradability of services, technological evolution, greater attention to product differentiation and processes of market liberalization and privatisation" are perceived to be the most relevant ones (Mangàni, 2006:257). His particular attention, however, is directed to the reduction of personal contacts between producers and consumers in the provision of services caused by technological developments: in this case, the heavy reliance on service marks may reflect an additional need for signalling the origin and quality to remote customers. Jensen and Webster (2004) make a similar observation about the growth of trademark activities in service sectors when analysing the recent trademark boom in Australia; yet, the authors are more inclined to associate it with substantial changes in the legislation, eventually permitting the registration of service marks. Furthermore, such factors as a shift in consumer demand for greater variety and quality, and the introduction of the Madrid Protocol that has affected trademarking in companies involved in international trade also deserve a special mention.

In contrast to some of the above findings, Herz and Mejer (2016) offer a much simpler explanation of the significant increase in national trademark applications observed over the past decades, at least when it comes to developed countries. Their analysis departs from the basic fact that "trademark filing fees have been steadily decreasing and converging across countries in Europe" (Herz and Mejer, 2016:1039). Using econometric techniques, they then calculate the sensitivity of trademarking behaviour to fee changes, which is equal to a $10.45 \%$ decrease in trademark applications following a $10 \%$ increase in the filing fee. Based on these estimations, they decompose the dynamics of trademark applications at 20 European offices over the last 20 years and conclude that it is largely driven by the fee adjustment process. It is worth additionally noting that their highest point estimate is potentially able to fully explain all the recently recorded increases in the number of trademark deposits.

Turning to the forces acting within an industry, Allegrezza and Guarda-Rauchs (1999) suggest that a company's propensity to trademark depends on market characteristics, such as the level of competitiveness, which effect is channelled via the monitoring of rivals' behaviour and especially of their ability to engage in product imitation. Similarly, Gallié and Legros (2012) demonstrate that the probability of using a trademark for the sake of protection varies and is greater for larger companies operating in more competitive markets. As for industry affiliation, their study indicates that companies in the manufacturing sector 
apply for fewer trademarks, unless they produce consumer goods. Based on an analysis of start-ups' decision on whether to file their initial intellectual property right in the form of a patent or trademark, De Vries et al. (2017) also come to the conclusion that industry factors matter. In particular, companies prioritise trademark protection when they face intense market competition or directly interact with final consumers. For such companies securing a unique selling position through trademark registration becomes part of the strategy for accessing the target market. The authors further report that receiving venture capital investment before the application date represents yet another reason for the decision to give preference to trademarks. Their interpretation of this association relies on the supposed willingness of venture capitalists to introduce a product in the marketplace as early as possible; hence, having a brand name legally protected seems to be essential before proceeding to the commercialisation stage.

\section{The effect of internal environment on trademark deposits}

Literature review. There are also a number of papers that attempt to detail intraorganisational factors influencing the extent of trademark activities. For example, Allegrezza and Guarda-Rauchs (1999) point to firm size, export orientation, and the attention of decision makers paid to trademark protection as one of the key factors that have a positive impact on trademark deposits. Jensen and Webster (2006), in turn, argue that firm size can well predict the intensity with which companies utilise various appropriability regimes. Among other things, their analysis shows that due to stronger innovation performance, small companies are more likely to apply for trademark protection than large corporations. Moreover, such companies tend to place a greater emphasis on intellectual property protection, including through trademark registrations, frequently owing to a lack of trust they have when transacting with external parties. To assess the extent to which the production process affects a firm's trademarking behaviour, Gao and Hitt (2012) propose to look at investments in information technologies. The conceptual framework they have developed is based on the assumption that technological advances can substantially lower the cost of offering greater product variety, with a corresponding effect on trademark applications and holdings. Their empirical analysis supports the idea that the amount of capital invested in information technologies has a positive relationship with the size of a firm's trademark portfolio; as for its relationship with trademark filings, it is also positive and potentially reflects an increased rate of new product introduction. To address the need for accurate accounting of intangibles, de Rassenfosse (2017) seeks to understand whether the level of investments in brand equity can be seen as a valid input measure of the demand for trademark rights. His analysis of 32 mostly developed countries reveals that advertising and market research expenditures have a significantly positive impact on trademark production. 
Finally, a study by Block et al. (2015) is particularly interesting in this literature stream because it makes an early attempt to capture the complexity of motives behind a firm's decision to apply for a trademark. In doing so, the authors draw on survey data from 600 small and medium enterprises in innovative industries and derive three major trademarking motives - protection, marketing, and exchange. By using cluster analysis, these motives are then combined into four groups, depending on which one the firm chooses to prioritise: trademark sceptics; marketing-focused trademarking companies; marketing and protectionfocused trademarking companies; and trademark advocates. Along with visible differences in trademarking behaviour existing across these groups, the authors also acknowledge the company's affiliation with the service sector, its reliance on innovation activities, external knowledge, and financial capital as further sources of group idiosyncrasies.

\section{Other determinants of trademark deposits}

Literature review. In addition to examining the determinants of trademark deposits in the private sector, there is new research entirely dedicated to trademark protection in academic institutions (see Squicciarini et al., 2012). Focusing on 621 U.S. universities, this research demonstrates that the number of enrolled students, the share of graduate students, the presence of a medical school, the amount of federal funding, the private status, and the intensity of patent activities - all this is positively associated with the number of trademark applications; at the same time, higher concentration of universities in the state reduces the propensity of a focal university to register a trademark. In fact, it may well be that networking with academic institutions also facilitates trademark activities undertaken by private companies. According to Doh and Kim (2014), small and medium enterprises in South Korea tend to apply for more trademarks if they have an established relationship with universities, which may reflect, among other things, the importance of technological and financial support available to regional companies through this particular channel. Their analysis additionally suggests that the number of $R \& D$ personnel negatively affects trademark registrations, although the authors do not elaborate on this finding.

\subsection{Trademarks and product differentiation}

General background. The predominant function of a trademark is to distinguish goods and services of one party from those of another. In order to avoid consumer confusion, formal protection can thus be afforded only to those marks that efficiently perform the differentiation function. An important issue here refers to the extent to which trademark data capture, for example, the quality dimension of product differentiation. According to Landes and Posner (1987:270), "[t]he value of a trademark is the saving in [consumer] search costs made possible by the information or reputation that the trademark conveys or embodies 
about the brand". However, companies would have little incentive to invest in activities related to brand promotion, unless there was a legal guarantee that a third party would be limited in its ability to imitate the brand and, as such, free-ride on the brand owner's reputation, thereby destroying the informational capital carried by a trademark. So, formal protection coupled with significant reputation-building expenditures is likely to lead the producer to maintain the quality level of products because the alternative is to incur reputational damage. It can then be deduced that the higher is the value of a trademark, the stronger will be the company's incentive to protect it so as to avoid financial losses associated with its infringement. Against this background, one can predict that "high quality producers have greater incentives to deposit their trademarks in several markets, both at a national and international level" (Mangàni, 2007:618).

\section{Product differentiation in international trade}

Literature review. A few studies have utilised trademark statistics to analyse variety and quality patterns in international trade. Fink et al. (2005:96), for example, examine data on trademark activities in more than one hundred countries and reveal that "the number of newly registered trademarks depends on the worldwide volume of exports from the source country in a particular industry". Other factors that can potentially influence trademark filings include economic and linguistic proximities between countries participating in international trade as well as their membership in the Madrid Protocol. Overall, the authors conclude that "richer countries tend to import products of higher quality and greater brand differentiation", with the effect being more pronounced in consumer goods and trademarkintensive industries (Fink et al., 2005:100). It should also be noted that the empirical strategy in this work is based on the assumption that a company's propensity to protect a trademark is associated with both product quality and the extent of brand differentiation. Fairly similar results were obtained by Mangàni (2007), who shows that trademark deposits are positively correlated with the size and wealth of an economy. Moreover, after decomposing the overall trademark entries into extensive, intensive, quantity, and quality margins, he reveals that country variations in trademark applications are mainly driven by differences in quantity within markets, while the quality effect turns out to be fairly negligible. Finally, a work by Baroncelli et al. (2007) looks at the discrimination against foreign trademark applicants as a potential barrier to imports. The starting point of this study is the observation that there are developing countries where the ratio of trademark registrations to applications is much higher for national applicants compared to foreigners. They then derive a theoretical model that attempts to explain these discrepancies by focusing on the product quality competition between domestic and foreign companies. Using the statistical analysis of trademark activities in China, Hong Kong, India, and South Africa, they find some signs of 
protectionist behaviour, especially in the situations when imported products are of similar quality to the ones produced locally.

\section{Competitive positioning}

Literature review. Several empirical papers have studied a company's competitive positioning vis-à-vis its rivals. More specifically, Semadeni (2006) focuses on service mark applications filed by management consulting companies in order to examine the competitive positioning of themselves as well as their service offerings. He reads through the description of each mark to determine its specialisation and innovation characteristics, which information is then used to calculate dyadic distances between mark pairs. His results suggest that companies attempt to differentiate themselves away from their immediate competitors, while still locating their services closer to similar services of other companies. Furthermore, positioning preferences very much depend on the age and size of a focal company: that is, older companies tend to reduce the competitive overlap with younger companies, which is in stark contrast to larger companies that prefer to enhance it. Another interesting observation this study has to offer is related to the positioning of prospective services - upon their introduction, all market players seek to establish an association with them. In a subsequent study, Semadeni and Anderson (2010) employ a similar analytical framework to assess a company's decision on whether to imitate or not a new offering, given environmental uncertainty and information asymmetries. Among multiple findings they present in this study, two are worth a special mention: on the one hand, the probability of imitation increases when the company perceives the innovating competitor as having the superior knowledge of the market; on the other hand, a highly innovative offering is less likely to be imitated because of the uncertainty and risks it is surrounded with. In turn, Crass and Schwiebacher (2017) argue that companies value trademark protection for its ability to reduce the likelihood of product substitution. Based on an analysis of the 2011 German Innovation Survey, they conclude that for service sector companies, the use of trademark protection per se is positively associated with a more product-differentiated environment. However, this effect is observed only when a company introduces product innovations which are new to the market, otherwise it fades away. The authors interpret these results in favour of the role of trademark protection in ensuring horizontal differentiation and enhancing the company's ability to appropriate rents from innovation activities. As for service sector companies that adopt imitation strategy, the portfolios of trademarks they have accumulated have a positive impact on the extent of product differentiation, thus suggesting differentiation through brand proliferation. 


\section{Historical studies of product differentiation}

Literature review. There are a couple of works that employ trademark statistics to explore differentiation issues in a historical context. One of them is a paper by LlonchCasanovas (2012) that examines the development of the Catalan knitwear industry over a period of 100 years. It particularly demonstrates that business location was among the most significant factors influencing a company's differentiation activities. When companies operated within industrial districts, with their atmosphere of rivalry and imitation, they had to facilitate differentiation by creating new brands and, hence, registering more trademarks. However, the survival of these brands very much depended on district characteristics, including the industrial structure and product specialisation as its key determinants. In turn, da Silva Lopes and Guimaraes (2014) look at the development of British dominance in light consumer goods industries over the period 1876-1914. Their analysis shows that technological and marketing innovations - originated either in the U.K. or abroad - laid a basis for the creation of sustained competitiveness in the selected industries; and the existence of intellectual property protection ensured that entrepreneurs were able to keep monopoly rents for subsequent years. Moreover, investing in new product development and branding allowed companies to expand their market share and to enjoy economies of scale, with trademark protection as a principal element in making this happen.

\subsection{Trademarks as an indicator of innovation activities}

General background. Unlike patents, trademarks should not necessarily be associated with a new good or service to warrant a registration, let alone to be introduced in the marketplace. Hence, the question arises: to what extent does trademarking behaviour correspond to innovation activities? To date, the literature has come up with two broad approaches to justifying the existence of the trademark-innovation link. The theoretical method appeals to the signalling function of a trademark (Landes and Posner, 1987) to argue that companies introduce new trademarks in order to increase consumer awareness of a new product variety in the marketplace. Following changes in consumer tastes, the producer may, for example, choose to design a new trademark for a newly developed product "that comes closer to the new tastes, while continuing to produce the old product" (Economides, 1988:530). However, with this argument alone, it is difficult to accurately assess the actual extent of the relationship in question, especially considering that companies may decide to leverage their existing brands - and, as such, acquired reputation - even for newly developed goods and services, thus causing fluctuations in the trademark flow regardless of innovation activities. 
So, a possible alternative is to rely on the empirical method that employs correlation analysis and uses it along with widely accepted indicators of innovation, such as R\&D expenditure or patenting, to see whether trademark statistics behave in a similar manner or not. The intuition here is that trademarks represent an output of the new product development process, which typically consists of research, development, and commercialisation phases (Jensen and Webster, 2009). Therefore, with an appropriate lag structure, the flow of trademarks is likely to match the level of preceding innovative activities in a company. Another variant of this method is to employ surveys and other available means to first distinguish innovative companies from the rest and then see if, on average, they introduce more trademarks. There are certain limitations associated with this method as well, including the fact that the actual introduction of a new trademark may not always coincide in time with filing a trademark application; and in services, companies rarely engage in patenting or extensive research activities, hence affording fewer opportunities for using correlation analysis.

\section{The use of service marks and innovation in the service sector}

Literature review. Allegrezza and Guarda-Rauchs (1999) are among the first who have presented empirical evidence regarding a potential link between innovation and trademark activities. They examine more than 2,500 small and medium enterprises in Benelux countries and come to a conclusion that a company's $R \& D$ expenditures are positively related to trademark deposits. Since then, considerable effort has been directed towards testing and verifying this link, especially in service sectors where the need to assess the extent of innovation activities seems to be particularly acute. For example, Schmoch (2003) places a special focus on service marks and shows that their use is significantly correlated with the share of turnover due to sales of new goods and services; as it turns out, the observed effect is much more pronounced in knowledge-intensive services. In another study, Schmoch and Gauch (2009) adopt an international perspective into the quantitative analysis of innovation activities by using trademark statistics. Among other things, they suggest that "the use of community trademarks proves to be insufficient for valid statistical analyses; international registrations combined with community trademarks should be used instead" (Schmoch and Gauch, 2009:323). In turn, Gotsch and Hipp (2012) demonstrate that although trademarks are generally a suitable indicator of innovation in knowledge-intensive services at large, their explanatory power is considerably greater for product innovations. This is broadly consistent with their subsequent study reporting that the protection of new goods and services is the most important motive for filing a trademark application (see Gotsch and Hipp, 2014). 


\section{Links to other indicators of innovation}

Literature review. An analysis of trademark use by Portuguese companies performed by Mendonça et al. (2004:1401) extends the above findings further by revealing that "hightechnology sectors, which use more patents, also make a more intensive use of trademarks", thereby pointing to an association between the two and, as such, the link of trademark filings to innovation activities. Similarly, Hall et al. (2013) demonstrate that a company's trademark activities are closely associated with patenting. Based on this and other results, they conclude that companies which are active in formal intellectual property protection attempt to exploit all the mechanisms available to ensure its full integrity. In addition, Hanel (2008) demonstrates that companies that have received $R \& D$ subsidies from the government are associated with more trademark applications; moreover, the use of patents and also trademarks seems to be mandatory for a successful innovation strategy. At the same time, after examining individual trademarks and their correspondence to new product launches, Malmberg (2005) shows that unlike the pharmaceutical industry where trademarks are tied to the number of new products, electromechanical and automotive sectors seem to be far less reliant on trademark activities when marketing innovative output. In turn, Gallié and Legros (2012) suggest that trademark applications are more likely in companies which are involved in the development of new production or distribution methods. To evaluate the relationship between innovation proxies, Jensen and Webster (2009) use both statistical and survey-based measures of innovation. Similar to other studies, they have identified a positive relationship between R\&D expenditures and trademark filings, with the effect being especially pronounced in service sectors. What is perhaps more interesting is that trademarks perform well when it comes to capturing innovation activities in the manufacturing industry. This conclusion is based on the fact that companies directly classifying themselves as innovative are associated with more trademark deposits. Their analysis additionally suggests that trademarks are particularly better at capturing product and marketing innovations. By combining information on trademark registrations and new products announcements, Flikkema et al. (2014) also confirm that most trademarks refer to innovation activities. According to their results, of two trademark categories - related to service delivery innovation and to innovative offering, the latter group is likely to be combined with other intellectual property rights.

Overall, we can conclude that the absolute majority of studies have generally agreed on that trademark statistics should be seen as a valuable source of information about a company's innovation activities. However, the efficiency of this indicator very much depends on a number of different factors, among which industry characteristics tend to prevail. Another point to make regarding the measure efficiency is related to innovation 
type: being a predominantly consumer-directed instrument, trademarks therefore have a significantly higher potential for capturing the extent of product and marketing innovations than other types of innovation.

\subsection{Trademarks and their strategic use}

General background. When introducing a new trademark, the company usually attempts to address two sorts of issues. On the one hand, different trademarks owned by the same company can be somehow interrelated. This interrelation is likely to be rooted in the company's brand strategy, which has three generic types - corporate branding, a house of brands, and mixed branding (Rao et al., 2004). Clearly, given the strategy type the company adopts, there will be variations not only in the number of newly introduced trademarks, but also in the potential costs and benefits that the chosen strategy brings to the company. On the other hand, trademark activities, especially when they follow the appropriation motive, can have a close association with other intellectual property rights. As Teece (1986) once famously suggested, a company's ability to profit from innovation over time largely depends on whether it can establish a prior position in complementarity assets as well as the characteristics of the appropriability regime in which it operates. From this perspective, the strategic use of trademarks may consist in pursuing value transference, with shifting "the advantages of technical or performance-based customer benefits (originally reserved in patents or copyrights) to trademarks" (Conley et al., 2013).

\section{Trademarks in relation to each other}

Literature review. A pioneering, albeit not well cited, study by Sandner (2009:1257) argues that "[c]ompany trademark portfolios are not loose agglomerations of trademarks but, instead, contain complex structures that coherently protect a company's brand, which may extend across multiple products, product categories, and services". To identify these structures, which are referred to as trademark families, the author decomposes trademark portfolios of 2,289 companies by examining the characters, words, and syllables contained in each trademark. Overall, he reveals two strategic options a brand manager faces when introducing a new trademark - either to start a new brand or to continue developing the existing brand. Should the latter option be selected, there are further alternatives to decide on, including whether to cover a different facet of the existing brand (hedging); to update the existing brand so that it still maintains its differentiation potential (modernising); or to leverage information capital embodied in the existing brand (extending). In a subsequent work, Block et al. (2014b) use the above classification to assess financial implications of trademarking strategies. Their results suggest that there are clear differences in the valuation of trademark families by financial markets, namely: "[w]hile financial markets place 
a premium on brand-developing trademarks [...], they do not value brand-creating trademarks and hedging trademarking strategies" (Block et al., 2014b:167). Furthermore, trademarking strategies that are based on brand modernisation or extension tend to have a positive impact on firm value, too. As the authors put it, advertising efficiency associated with brand extension increases the chances of a company to succeed with launching a new product or entering a new market; yet, brand modernisation is valued because of its role in maintaining the strength and attractiveness to consumers of the company's existing brands.

Another aspect of strategic trademarking refers to so-called trademark cluttering. According to von Graevenitz et al. (2012:5), "cluttered trade mark registers [... are] registers containing such a large number of unused or overly broad trade marks, that the costs of creating and registering new marks substantially increase for other applicants". It should be noted that there are many reasons, and they are not necessarily related to fraudulent or deceptive practices, why certain trademarking strategies cause the cluttering effect. For example, trademark applications may be filed in more product classes than needed; companies applying for more trademarks genuinely anticipate an extension of their product lines and, therefore, attempt to secure certain names associated with existing brands beforehand; as well as multiple trademark applications can also be due to name regulation in such industries as pharmaceuticals. As for the latter, von Graevenitz (2013) gives a detailed account of this phenomenon by using enlargement of the European Union as a natural experiment to examine the effect of cluttering on trademarking in the pharmaceutical sector. His results demonstrate that regulatory uncertainty may provoke a significant increase in companies' propensity to trademark invented names which they will unlikely to use. This behaviour is largely caused by the fear that some of these names may be rejected by the regulator to prevent medication error due to confusing or overly similar names in other jurisdictions, thus leaving companies with no registered trademarks at all. Additionally, he provides monetary estimates of the cost effect stemming from the surplus of invented names: his conservative assumption for the lower bound lies in the range between USD $21 \mathrm{~m}$ and USD 49m per year. In turn, Fink et al. (2014:3) consider a sister concept to trademark cluttering - trademark squatting, which "describes a situation in which a company or individual registers a trademark that protects a good, service, or trading name of another company". This strategy is likely to be especially harmful for companies that operate across national borders because squatters can substantially delay their foreign market entry. What is perhaps more insightful in this respect is the strategic response companies develop to minimise or even avoid trademark squatting. Using data on trademark oppositions, Fink et al. (2014) show that, once having experienced squatting, brand owners inflate trademark 
filings by registering a disproportionately large number of new trademarks in areas which are not directly related to their current business activities.

\section{Trademarks in relation to other intellectual property rights}

Literature review. There are also several papers that point to the complementarity existing between trademarks and other appropriability regimes. Unlike prior research that pointed to the substitutability aspect of some protection mechanisms, Graham and Somaya (2006) attempt to verify the hypothesis that intellectual property rights actually complement each other. After examining patent, copyright, and trademark litigation statistics on the top 100 U.S. packaged software companies, they confirm that companies use trademarks and copyrights as complements. Furthermore, they also show that this effect is mainly driven by the attention paid by top managers to intellectual property issues as well as by organisational resources that can be utilised across different protection areas. A work by Munari and Santoni (2009) provides additional empirical evidence to support the complementarity hypothesis. Their analysis of 425 small and medium enterprises in Italy shows that companies tend to favour a joint use of patents and trademarks; moreover, those companies that complement patents with trademarks perform better than those without intellectual property rights. Amara et al. (2008) extend these findings further to the case of the joint use of formal and informal protection methods. Their analysis of 2,625 innovative service establishments in Canada demonstrates that "trademarks are complementary to patents, copyrights, and confidentiality agreements [..., while being] independent from secrecy, complexity of designs, and lead-time advantages" (Amara et al., 2008:1541). They conclude that companies do not perceive intellectual property protection as a collection of isolated instruments; instead, corporate managers attempt to exploit synergies stemming from different protection methods to secure innovative output. Gallié and Legros (2012), in turn, demonstrate that trademark protection is negatively correlated with - or is a substitute to each non-statutory method and especially with lead-time advantages. But what can influence the company's decision to complement one protection method with another? Using data on patent and trademark activities in French companies, a study by Llerena and Millot (2013) attempts to provide an answer. It identifies significant differences across economic sectors, namely: patents and trademarks complement each other in chemical and pharmaceutical sectors, while acting as substitutes in high-tech business sectors. The joint use of patents and trademarks is largely due to the advertising factor, with high advertising spillovers and a low advertising depreciation rate leading to patents and trademarks being used as complements. 


\section{Trademarks and entrepreneurial activities}

Literature review. The use of trademarks is sometimes considered in relation to entrepreneurial activities. For example, a work by Lechner et al. (2016) suggests that vertical disintegration is likely to result in the separation of brands from upstream activities. As such, this may create entrepreneurial opportunities in terms of selling, acquiring, and reselling brands via market transactions. By looking at trademark assignments in the U.S. manufacturing sector, the authors confirm the above hypothesis as well as point to the positive relationship between the degree of vertical disintegration and the size of the market for brands. In turn, Goel et al. (2016) argue that formal and informal entrepreneurs can benefit from knowledge spillovers associated with intellectual property rights. Using trademarks to capture the flows of innovative, yet non-patentable knowledge, the authors demonstrate that an increase in trademark applications has a positive and statistically significant effect on formal entrepreneurship; however, the effect turns insignificant when informal entrepreneurs are focused on. It is also found that the spatial effect of trademark applications is negative, thus indicating that "neighboring trademarks are based on countryspecific norms and traditions that generally do not transfer well across borders" (Goel et al., 2016:306).

\section{Trademark lifecycle}

Literature review. There are studies that look at the trademark lifecycle and its determinants. By employing U.S. trademark statistics, Millot (2009) shows that the absolute majority of marks die six-to-seven years after the registration date simply because the owner fails to confirm that the trademark is still in commercial use. A large share of marks is then unable to survive the ten-to-eleven-year period when the owner is legally obliged to renew the mark registration. Against this background, Gao and Hitt (2012) argue that significant improvements in information technologies have resulted in more frequent updates in product lines. Therefore, companies with higher information technologies capital may actually be associated with a shorter trademark lifecycle. Using the Australia retail grocery industry as an exemplary setting, Jensen and Webster (2008), in turn, demonstrate that trademark age is positively related to consumer demand. However, this is effective only up to a point - if the company fails to keep up with investment in branding activities to match ever changing consumer preferences, a decline in consumer loyalty will result in inability to leverage it. A work by Melnyk et al. (2014) provides insights into what affects trademark prolongations. They examine 2,911 trademarks in the U.S. software security industry and come to a conclusion that larger and more innovative companies often terminate their trademarks earlier; at the same time, older companies are more likely to opt for the prolongation of 
a trademark. As for trademark characteristics, trademark age and the number of product classes in which it is registered both increase the probability of prolongation.

\subsection{Trademarks and organisational performance}

\section{Market value gains from trademarking}

General background. The strategic value of intangible resources consists in their ability to contribute towards sustaining a company's competitive position; given that, it needs to be accounted for and, ideally, also included in shareholders' funds (Hall, 1992). However, the question arises: what exactly can the source of such value be? As far as trademarks are concerned, their close association with the reputation of the underlying product or producer and, as such, a significant power to influence consumer choice - seems to be a plausible answer (Landes and Posner, 1987). This power can be gained through advertising, product quality, servicing, and other methods which aim to first induce consumer loyalty and then transform it into higher sales and the willingness to pay a premium for the branded product, thereby allowing the company to obtain greater profits (Chamberlin, 1933). Although most of the mark's value is inseparable from the product to which it is affixed, some trademarks can have value of their own and, hence, should themselves be seen as a legitimate good (Landes and Posner, 1987; Economides, 1988). It is also true that the value of a trademark exists as long as there is some sort of formal protection; if not, competitors will have a strong incentive to imitate the trademark and, by deliberately provoking consumer confusion, appropriate some of the benefits associated with it (Landes and Posner, 1987).

A commonly used approach to estimating the private returns to trademark activities is based on linking the valuation placed by the financial market on a company's total assets to its trademark applications or holdings (Hall, 1999; Bosworth and Rogers, 2001). As the argument goes, when determining the company's value, financial markets consider not only the tangible assets that appear on its balance sheet, but also intangible assets, such as R\&D expenditures, patents, and trademarks. Therefore, the following valuation function can be specified (Griliches, 1981):

$$
V=q \cdot(A+K)^{\sigma},
$$

where $V$ is the current market value of the company; $A$ is the current value of tangible assets (on the balance sheet); $K$ is the current value of intangible, or knowledge, assets (off the balance sheet); $q$ is the current market valuation coefficient of the company's assets that reflects its differential risk and monopoly position; and $\sigma$ is a coefficient that reflects the possibility of non-constant returns to scale. If trademarks are treated as an asset that is 
symmetrical to other knowledge assets then their value can be incorporated in the formula simply by augmenting $K$ with it (Sandner and Block, 2011).

Literature review (see Table 3.1 for a summary of the results). In the paper by Bosworth and Rogers (2001), the authors apply the above method to estimate returns to innovation activities in large Australian companies. This work is among the first that looks beyond $R \& D$ spending and patents, and also points to trademarks and designs as an additional source of the company's market value. Despite a solid theoretical grounding, the results obtained by the authors are fairly ambiguous: that is, they are unable to find any statistically significant evidence to support the argument that the intensity of trademark applications influences market value if the full sample is considered. At the same time, a positive association between trademark activities and market value emerges when the sample is limited to non-manufacturing companies. Furthermore, the authors' estimates suggest that "a trade mark application has a private value of less than half that of a patent application" (Bosworth and Rogers, 2001:331), but without knowing the cost structure on which each of these instruments relies, no definitive conclusion can be made regarding their overall value efficiency. Similar findings are demonstrated by Feeny and Rogers (2003) when they construct an index to compare the innovation potential of Australian companies. In order to obtain the weight for each intangible asset and then use it to aggregate the assets into a single index, the authors measure the average impact of $R \& D$ expenditures, patents, trademarks, and designs, on the company's market value. As before, they reveal that the economic effect of trademark intensity is not statistically different from zero.

Greenhalgh and Rogers (2006a) conduct a more detail investigation of sectoral disparities observed in the market valuation of trademark activities. Using U.K. intellectual property statistics, they come to a conclusion that a more intensive use of trademarks in service sectors yields a higher stock market premium. And this result stands in stark contrast to transport, communication, utilities, and manufacturing industries - even though the popularity of trademarks there is still high, they have no sizable impact on the value that the financial market places on companies in these sectors. In turn, a study by Greenhalgh and Rogers (2006b) examines returns to innovation activities in U.K. companies that belong to Pavitt technological sectors. Their findings indicate that the intensity of trademark applications positively affects market valuation across all Pavitt sectors, except for the information intensive sector where this effect turns out to be negative. They also mention that for the full sample, "higher market share boosts the stock market's valuation of trade marking, but within the Pavitt sectors there are some that follow this result [...], whereas others have the converse relationship" (Greenhalgh and Rogers, 2006b:576-577). Finally, Greenhalgh and Rogers (2012) corroborate these results by revealing a greater influence that 
trademark activities in the past period have on the current market value, with service sector companies enjoying a much large effect than those operating in the manufacturing sector. As for trademark intensity in a given year, its relationship with market value is curvilinear, which effectively implies diminishing returns from adding an extra trademark to the existing portfolio. The authors additionally report that a higher level of trademark intensity in the industry tends to boost the focal company's market value, albeit this rule does not apply to service sectors. It seems that such an industry effect is associated with both an increasing pressure for laggards to innovate, as they face a significant risk of losing their market share, and the optimism with which investors evaluate the ability of those companies to close the gap with more innovative competitors.

A more careful explication of how a rival's product innovation and new advertising may affect the focal company's market value is offered by Fosfuri and Giarratana (2009). Their research is particular concerned with the competition between Pepsi and Coca-Cola in the carbonated soft drink market over the period 1999-2003. They rely on new product announcements to measure product innovation, whereas new advertising is proxied by the number of trademark filings. First of all, their results are generally in line with past findings pointing to the positive impact a company's innovation and trademark activities have on its valuation by the financial market. What is perhaps more interesting is that a new trademark filed by a rival also increases the capitalisation of the focal company. As the authors put it, new advertising tends to attract new customers and, as such, boosts total demand, whereas the distribution of market shares stays unaffected. By contrast, a new product released by a rival reduces the market value of the focal company because product innovation triggers the reallocation of market shares in favour of the innovator.

In turn, Sandner and Block (2011) approach the valuation problem from a slightly different end. They particularly argue that trademarks are not homogeneous and can be distinguished with respect to their own value; as such, these differences have to be accounted for when assessing returns to trademark activities. The authors come up with four indicators that are potentially capable of capturing trademark value, namely: (1) trademark breadth, or the number of product classes covered by a mark; (2) trademark seniority, or the number of marks registered in other jurisdictions; (3) trademark oppositions brought by an applicant; and (4) trademark oppositions received by an applicant. Overall, their multi-country analysis reveals that financial markets assign a higher value to companies with larger trademark portfolios. However, when a trademark's own value is considered, higher returns are associated with more senior trademarks as well as those trademarks for which the owner filed an opposition against another company. The authors thus conclude that "[b]y filing an own trademark or an opposition against a rival's trademark, firms show to the financial 
markets that they are eager to protect their marketing investments [..., and stock] markets seem to value such activity" (Sandner and Block, 2011:983).

Another research that deserves a special mention is a study by Krasnikov et al. (2009), where the authors make an early attempt to understand the extent to which financial returns to trademark activities may depend on the brand strategy associated with each trademark. The authors come up with a classification according to which trademarks are different in their aim to enhance either consumer awareness of or association with the underlying brand. As the argument goes, the former group of trademarks is valued because it enables the company to distinguish itself from other competing brands, whereas the latter because it helps the company to manipulate its consumers' brand-related attitudes. Their analysis of 108 U.S. companies from 14 industries suggests that the existing stock of brandassociation trademarks increases the company's future Tobin's q and stock returns. At the same time, the stock of brand-identification trademarks built up by the company during the previous period is found to significantly reduce the current positive impact of brandassociation trademarks on Tobin's q and stock returns. According to the authors, a possible explanation for such a negative effect is that "the brand-awareness efforts of firms attract more individual investors to their stocks, thereby attenuating the stock returns and Tobin's $q$ value of such firms" (Krasnikov et al., 2009:163).

Trademarks are also shown to be a useful signalling mechanism that companies can employ in their communication with potential investors, especially in situations with high uncertainty and large information asymmetries. For example, Block et al. (2014a:540) examine trademark activities in U.S. start-up companies and come to a conclusion that "[t]he number of trademarks and the breadth of their applications [...] provide additional information regarding the scope and direction of start-ups' marketing strategies". So, when making their investment decisions, venture capitalists include this information into the final valuation of a start-up. However, the strength of the signalling effect declines over the venture cycle: as soon as more tangible information about the start-up's operation becomes available, venture capitalists prefer instead to rely on it for guiding their further investment strategy. In a subsequent work, Zhou et al. (2016) demonstrate that combining trademarks with patents can help start-ups to attract a larger amount of venture capital than when just one of these instruments is used. The reason behind such a synergistic effect is that along with the enhanced protection of intellectual property, having both patents and trademarks registered also indicates the start-up's innovation potential and its firm intention to proceed with the commercialisation of a new product. As in the prior study, the signalling effect appears to influence venture capitalists' decision making inasmuch as no other valuable information is available, and tends to fade away in later funding rounds. 
Finally, there are two studies that provide insights into the market valuation of trademark activities in specific industries. To start with, there is a work by González-Pedraz and Mayordomo (2012) that makes an attempt to estimate financial returns to trademarking in the U.S. commercial banking sector. Among other things, the authors report a lower value assigned by the financial market to banks with a diverse trademark portfolio. Moreover, banks that maintain a stock of relatively young trademarks tend to be valued higher and are likely to improve their valuation further if decide to substitute older trademarks with younger ones. The event analysis they also conducted reveals abnormal returns or losses around the date when a trademark is introduced or cancelled, respectively. In turn, Aksoy-Yurdagul (2015) addresses the problem of value appropriation existing in the open-source software sector. He points out that a company's ability to reap financial benefits associated with commercialising open-source products very much depends on its stock of software patents and trademarks. Using data on 70 largest software producers, he shows that a larger stock of software trademarks has a negative effect on the relationship between the company's opensource product portfolio and market value. This outcome is consistent with his initial hypothesis that developing a strong software brand may not be fully compatible with the open-source business model because investing in related marketing activities is unlikely to result in higher cash flows in the future and, if pursued, will be viewed by the financial market in negative light.

\section{Productivity gains from trademarking}

General background. Another commonly used approach to quantifying economic returns to trademark activities is by linking them to total factor productivity (Hall, 1999). According to Duygun et al. (2016), the rationale behind this relationship is largely based on the ability of a trademark to stimulate consumer demand. In turn, the company can respond to an increase in demand by selecting one of the following options: first of all, it may choose to use up some of its excess capacity and, by doing this, improve operational efficiency. If there is no spare capacity left, the company may decide to expand inputs - this is likely to increase the scale of production, with a corresponding effect on the returns to scale. Finally, the company may also adopt a new technology that enables it to produce more output, while keeping inputs at the same or even lower level. Duygun et al. (2016:S71) note that the "relationship between trademarking activity, technical change and eventually TFP growth can be particularly relevant to firms which tend to invest more in the development of innovative production technologies and therefore tend to be the technological leaders in their industry". Overall, these actions will ultimately lead to the growth in total factor productivity. 
Table 3.1. A summary of the results on market value gains from trademarking

\begin{tabular}{|c|c|c|c|c|c|}
\hline Paper & Country & $\begin{array}{c}\text { Dependent } \\
\text { variable }\end{array}$ & $\begin{array}{c}\text { Trademark- } \\
\text { based measure }\end{array}$ & $\begin{array}{l}\text { Effect } \\
\text { range }\end{array}$ & $\begin{array}{c}\text { Significance } \\
\text { level }\end{array}$ \\
\hline $\begin{array}{l}\text { Bosworth and } \\
\text { Rogers (2001) }\end{array}$ & Australia & $\begin{array}{l}\text { Log of } \\
\text { market value }\end{array}$ & $\begin{array}{l}\text { Trademarks/ } \\
\text { tangible assets }\end{array}$ & $0.605-0.786$ & N.S. \\
\hline $\begin{array}{l}\text { Feeny and } \\
\text { Rogers (2003) }\end{array}$ & Australia & $\begin{array}{l}\text { Log of } \\
\text { market value }\end{array}$ & $\begin{array}{l}\text { Trademarks/ } \\
\text { tangible assets }\end{array}$ & $0.942-1.132$ & N.S. \\
\hline $\begin{array}{l}\text { Greenhalgh and } \\
\text { Rogers }(2006 \mathrm{~b})\end{array}$ & U.K. & $\begin{array}{c}\text { Log of } \\
\text { market value }\end{array}$ & $\begin{array}{l}\text { Trademarks/ } \\
\text { total assets }\end{array}$ & $\begin{array}{c}0.073 \\
\text { (for full sample) }\end{array}$ & N.S. \\
\hline \multirow{3}{*}{$\begin{array}{l}\text { Fosfuri and } \\
\text { Giarratana (2009) }\end{array}$} & \multirow{3}{*}{ U.S. } & Tobin's q & $\begin{array}{l}\text { Number of } \\
\text { trademarks }\end{array}$ & $\begin{array}{l}\text { Rival: } 0.576 \\
\text { Firm: } 3.244\end{array}$ & $\begin{array}{l}\text { Rival: } 5 \% \\
\text { Firm: } 5 \%\end{array}$ \\
\hline & & $\begin{array}{l}\text { Market } \\
\text { share }\end{array}$ & $\begin{array}{l}\text { Number of } \\
\text { trademarks }\end{array}$ & $\begin{array}{l}\text { Rival: } 0.726 \\
\text { Firm: } 0.614\end{array}$ & $\begin{array}{l}\text { Rival: N.S. } \\
\text { Firm: N.S. }\end{array}$ \\
\hline & & Total demand & $\begin{array}{l}\text { Number of } \\
\text { trademarks }\end{array}$ & $\begin{array}{l}\text { Rival: } 0.015-0.022 \\
\text { Firm: } 0.064-1.783\end{array}$ & $\begin{array}{l}\text { Rival: } 5 \% \\
\text { Firm: } 5 \%\end{array}$ \\
\hline \multirow{2}{*}{$\begin{array}{l}\text { Krasnikov et al. } \\
(2009)^{*}\end{array}$} & \multirow{2}{*}{ U.S. } & Tobin's q & $\begin{array}{c}\text { Stock of } \\
\text { trademarks }\end{array}$ & $\begin{array}{c}\text { BI: } 0.007 \\
\text { BI*BA: }-0.0001\end{array}$ & $\begin{array}{c}\text { BI: } 5 \% \\
\text { BI*BA: } 5 \%\end{array}$ \\
\hline & & $\begin{array}{l}\text { Stock } \\
\text { returns }\end{array}$ & $\begin{array}{c}\text { Stock of } \\
\text { trademarks }\end{array}$ & $\begin{array}{c}\text { BI: } 0.003 \\
\text { BI*BA: }-0.0001\end{array}$ & $\begin{array}{c}\text { BI: } 5 \% \\
\text { BI*BA: } 5 \%\end{array}$ \\
\hline $\begin{array}{l}\text { Sandner and } \\
\text { Block (2011) }\end{array}$ & $\begin{array}{l}\text { Multiple } \\
\text { countries }\end{array}$ & Tobin's q & $\begin{array}{l}\text { Trademark stock/ } \\
\text { marketing assets }\end{array}$ & $11.368-13.504$ & $1 \%$ \\
\hline $\begin{array}{l}\text { González-Pedraz } \\
\text { and Mayordomo } \\
(2012)\end{array}$ & U.S. & Tobin's q & $\begin{array}{l}\text { Trademark stock/ } \\
\text { total employees }\end{array}$ & $\begin{array}{l}\text { Linear: }-10.417 \\
\text { Quad.: } 627.764\end{array}$ & $\begin{array}{l}\text { Linear: } 1 \% \\
\text { Quad.: } 10 \%\end{array}$ \\
\hline \multirow{2}{*}{$\begin{array}{l}\text { Greenhalgh and } \\
\text { Rogers (2012)** }\end{array}$} & \multirow[t]{2}{*}{ U.K. } & \multirow{2}{*}{$\begin{array}{l}\text { Log of } \\
\text { market value/ } \\
\text { tangible } \\
\text { assets }\end{array}$} & $\begin{array}{l}\text { Trademark } \\
\text { dummy }\end{array}$ & $\begin{array}{c}\text { UM: } 0.221 \\
\text { CM: } 0.316 \\
\text { UM+CM: } 0.396 \\
\text { (for full sample) }\end{array}$ & $\begin{array}{c}\text { UM: } 1 \% \\
\text { CM: } 1 \% \\
\text { UM+CM: } 1 \%\end{array}$ \\
\hline & & & $\begin{array}{l}\text { Trademarks/ } \\
\text { tangible assets }\end{array}$ & $\begin{array}{c}\text { UM: } 0.049 \\
\text { CM: } 0.006 \\
\text { (for full sample) }\end{array}$ & $\begin{array}{l}\text { UM: N.S. } \\
\text { CM: N.S. }\end{array}$ \\
\hline \multirow{2}{*}{$\begin{array}{l}\text { Block et al. } \\
(2014 \mathrm{a})\end{array}$} & \multirow[t]{2}{*}{ U.S. } & \multirow{2}{*}{$\begin{array}{c}\text { Log of } \\
\text { start-up } \\
\text { valuation }\end{array}$} & $\begin{array}{l}\text { Number of } \\
\text { trademarks }\end{array}$ & $\begin{array}{c}\text { Dummy: } 0.223 \\
\text { Linear: } 0.033 \\
\text { Quad.: }-0.0001\end{array}$ & $\begin{array}{c}\text { Dummy: } 1 \% \\
\text { Linear: } 1 \% \\
\text { Quad.: } 1 \%\end{array}$ \\
\hline & & & $\begin{array}{c}\text { Number of } \\
\text { trademark classes }\end{array}$ & $\begin{array}{l}\text { Linear: } 0.165 \\
\text { Quad.: }-0.015\end{array}$ & $\begin{array}{l}\text { Linear: } 1 \% \\
\text { Quad.: } 1 \%\end{array}$ \\
\hline $\begin{array}{l}\text { Aksoy-Yurdagul } \\
\text { (2015) }\end{array}$ & $\begin{array}{c}\text { Fortune } \\
\text { Global } 500\end{array}$ & Tobin's q & $\begin{array}{c}\text { Stock of } \\
\text { trademarks }\end{array}$ & 0.027 & N.S. \\
\hline $\begin{array}{l}\text { Zhou et al. } \\
(2016)^{* * *}\end{array}$ & U.S. & $\begin{array}{c}\text { Log of } \\
\text { amount of } \\
\text { VC funding }\end{array}$ & $\begin{array}{c}\text { Trademark } \\
\text { dummy }\end{array}$ & $\begin{array}{l}\text { AR: } 0.238 \\
\text { IR: } 0.118 \\
\text { LR: } 0.413\end{array}$ & $\begin{array}{l}\text { AR: } 5 \% \\
\text { IR: N.S. } \\
\text { LR: } 10 \%\end{array}$ \\
\hline
\end{tabular}

* BI refers to brand-identification trademarks; BA refers to brand-awareness trademarks. ** UM refers to UK trademarks; CM refers to community trademarks. *** AR refers to all funding rounds; IR refers to the initial funding round; LR refers to the later funding round. N.S. stands for "not significant". 
In order to estimate the effect of productivity gains due to trademarking on the company's total output, the Cobb-Douglas production function can be utilised (see Greenhalgh and Rogers, 2012):

$$
Y=A \cdot L^{\alpha} \cdot K^{\beta}
$$

where $Y$ is total output; $L$ is the stock of labour; $K$ is the stock of tangible capital; $A$ is total factor productivity; and $\alpha$ and $\beta$ are the output elasticities of labour and capital, respectively. Then the effect of trademarks as well as other intangible assets can be incorporated as follows:

$$
A=f(R, P, H K, I T, T M),
$$

where $A$ is total factor productivity; $R$ is the stock of $\mathrm{R} \& \mathrm{D}$ expenditures; $P$ is the stock of patents; $H K$ is the stock of human capital; IT is the stock of information technology; and TM is the stock of trademarks. Greenhalgh and Longland (2005) show that the stock measures of R\&D expenditures, patents, and trademarks can be replaced with flow measures when the rate of depreciation is very high.

Literature review (see Table 3.2 for a summary of the results). Turning to empirical studies, a work by Greenhalgh and Longland (2005) demonstrates that the intensity of trademark applications has a positive effect on the company's net output. However, this effect is mainly driven by low-tech companies, whereas there is no direct evidence of productivity gains from trademark activities in the high-tech sector. Along with short-lived benefits of intellectual property protection, this may also indicate that "firms, especially those in the most dynamic sectors, have to keep innovating in order to preserve their productivity ranking in relation to their competitors" (Greenhalgh and Longland, 2005:308). Similarly, a study by Greenhalgh and Rogers (2012) reveals that companies can enjoy a large value-added premium at present if they applied for a trademark in the past period, with the effect being generally higher for companies in the service sector. Moreover, the authors also report a strongly non-linear effect of trademark intensity on value added; taking into account a similar pattern for market value, they conclude that "stock markets are well informed about the gains to firms from their trade mark activity" (Greenhalgh and Rogers, 2012:65). Finally, it appears that the dynamism of trademark activities in an industry has a detrimental impact on the focal company's value added, which may be associated with a Schumpeterian competition through innovation.

Unlike the above cross-sectoral studies, Duygun et al. (2016) focus on the effect of trademark activities on the productivity of commercial banks in the U.K. Their analysis is based on a metafrontier framework that, among other things, allows the authors to decompose total factor productivity growth into "changes of efficiency, technical change and 
scale change for each group of commercial banks as well as the whole sector" (Duygun et al., 2016:S78). Their results reveal substantial differences between trademarking and nontrademarking banks in terms of their overall productivity and the factors that underpin it. That is, before the 2007-2009 financial crisis the productivity growth in trademarking banks was mainly supported by changes in technical efficiency; however, the technological progress took place only in a small number of such banks, while other trademarking banks were unable to catch up with the metafrontier. At the same time, the trend clearly reversed in 2009 , with the productivity growth in trademarking banks being now negative. The authors explain the observed effect by a dramatic reduction in lending, which has also pushed some banks to revisit their scale efficiency. By contrast, the productivity of non-trademarking banks showed no signs of significant growth in the pre-crisis period and started improving just after the crisis' most cute phase. It seems that having exploited the major gains associated with the scale efficiency model, these banks have eventually turned their attention to new technologies as a source of productivity growth.

Table 3.2. A summary of the results on productivity gains from trademarking

\begin{tabular}{|c|c|c|c|c|c|}
\hline Paper & Country & $\begin{array}{l}\text { Dependent } \\
\text { variable }\end{array}$ & $\begin{array}{c}\text { Trademark- } \\
\text { based measure }\end{array}$ & $\begin{array}{l}\text { Effect } \\
\text { range }\end{array}$ & $\begin{array}{c}\text { Significance } \\
\text { level }\end{array}$ \\
\hline $\begin{array}{l}\text { Greenhalgh and } \\
\text { Longland (2005) }\end{array}$ & U.K. & $\begin{array}{c}\text { Log of } \\
\text { added value }\end{array}$ & $\begin{array}{l}\text { Trademark stock/ } \\
\text { total employees }\end{array}$ & $\begin{array}{c}2.540-4.200 \\
\text { (for full sample) }\end{array}$ & $10 \%$ \\
\hline \multirow{2}{*}{$\begin{array}{l}\text { Greenhalgh and } \\
\text { Rogers }(2012)^{*}\end{array}$} & \multirow{2}{*}{ U.K. } & \multirow{2}{*}{$\begin{array}{c}\text { Log of } \\
\text { added value }\end{array}$} & $\begin{array}{l}\text { Trademark } \\
\text { dummy }\end{array}$ & $\begin{array}{c}\text { UM: } 0.107 \\
\text { CM: } 0.083 \\
\text { UM+CM: } 0.274 \\
\text { (for full sample) }\end{array}$ & $\begin{array}{c}\text { UM: } 1 \% \\
\text { CM: } 5 \% \\
\text { UM+CM: } 1 \%\end{array}$ \\
\hline & & & $\begin{array}{l}\text { Trademarks/ } \\
\text { tangible assets }\end{array}$ & $\begin{array}{c}\text { UM: } 0.246 \\
\text { CM: }-0.009 \\
\text { (for full sample) }\end{array}$ & $\begin{array}{l}\text { UM: N.S. } \\
\text { CM: N.S. }\end{array}$ \\
\hline
\end{tabular}

* UM refers to UK trademarks; CM refers to community trademarks. N.S. stands for "not significant".

\section{Profitability gains from trademarking}

General background. There are three perspectives from which the association of trademark activities with a company's profitability can be considered. First of all, by differentiating its product offering from that of competitors, a company may induce brand loyalty and, under certain conditions, charge customers a price premium for its goods and services (Chamberlin, 1933; Landes and Posner, 1987). Along with customer-related effects, trademark activities are also likely to influence the competitive regime existing in the marketplace: for example, they are often used to create barriers to market entry, which, in turn, are expected to lead to higher industry concentration (Bain, 1956). And as practice shows, the chances are that in more concentrated industries, incumbents will eventually 
adhere to collusive behaviour, with collusive prices and abnormal profits as its most notable manifestations (Griffith et al., 2011). Finally, there is a perspective that looks at trademarks in terms of their presumed link to the new product development process (Greenhalgh and Rogers, 2012; Duygun et al., 2013). Provided that the link holds, trademarks can then be employed to measure the effect of the Schumpeterian competition on a company's cost and profit efficiency because it is believed that such a competitive regime facilitates constant revisions of production methods in order to improve the overall firm performance.

Literature review (see Table 3.3 for a summary of the results). While trying to understand what may cause abnormal profits to emerge and persist over time, Griffith et al. (2011) suggest focusing on intangible resources: they particularly argue that along with tangible capital, these resources should also be accounted for to obtain more accurate profit estimates. The analysis they conducted by using Australian intellectual property statistics indicates that patent and trademark stocks have a positive and significant impact on a company's profit earning potential, thus supporting the authors' original idea regarding the need for the intangible capital-adjusted measure of profits. At the same time, neither patents nor marketing practices and branding seem to be important for explaining abnormal profits as those are mainly driven by industry collusion and a company's abuse of its market power. Similarly, Krasnikov et al. (2009) demonstrate that the existing stock of brand-association trademarks has a positive effect on future return on assets. Future cash flows are also shown to be positively influenced, including a substantial reduction in their variability. In turn, a study by Marco-Lajara et al. (2016:4560) draws specific attention to the role of trademarks in ensuring profitability in the hotel industry, which is largely due to their tight association with hotel reputation.

Additionally, there is a series of studies that evaluate profitability gains from trademark activities in the banking sector. In their first work, Duygun et al. (2013) approach the profit efficiency problem by looking at how banks compete through product innovation, which, as they argue, has been of not lesser importance for bank profitability than price competition. Their results generally confirm the idea that trademarking banks are more profit efficient compared to non-trademarking ones. However, the relationship between the industry-wide trademark intensity and a bank's profit efficiency is shown to be curvilinear. That is, launching a new product by one bank is likely to increase cost inefficiencies in the sector as it challenges the market shares of other banks. The downward pressure on profit efficiency caused by cost revisions will, in turn, subside only with an increase in industry competition. In a subsequent study, Duygun et al. (2014:507) reveal that trademarking and non-trademarking banks share the same cost and profit frontier, "although there exists some circumstantial evidence that the assumption of a common alternative profit frontier may be 
rejected for the period before 2008". They also re-confirm that trademarking banks are more profit efficient, although there is a group of banks that have a potential to benefit from trademark activities but cannot do it, presumably due to a lack of innovation activities.

Table 3.3. A summary of the results on profitability gains from trademarking

\begin{tabular}{|c|c|c|c|c|c|}
\hline Paper & Country & $\begin{array}{c}\text { Dependent } \\
\text { variable }\end{array}$ & $\begin{array}{c}\text { Trademark- } \\
\text { based measure }\end{array}$ & $\begin{array}{l}\text { Effect } \\
\text { range }\end{array}$ & $\begin{array}{c}\text { Significance } \\
\text { level }\end{array}$ \\
\hline \multirow{3}{*}{$\begin{array}{l}\text { Krasnikov et al. } \\
(2009)^{*}\end{array}$} & \multirow{3}{*}{ U.S. } & Cash flows & $\begin{array}{c}\text { Stock of } \\
\text { trademarks }\end{array}$ & $\begin{array}{c}\text { BI: } 7.820 \\
\text { BI*BA: } 0.019\end{array}$ & $\begin{array}{c}\text { BI: } 5 \% \\
\text { BI*BA: } 5 \%\end{array}$ \\
\hline & & $\begin{array}{l}\text { Cash flow } \\
\text { variability }\end{array}$ & $\begin{array}{c}\text { Stock of } \\
\text { trademarks }\end{array}$ & $\begin{array}{c}\text { BI: }-0.044 \\
\text { BI*BA: } 0.001\end{array}$ & $\begin{array}{c}\text { BI: } 5 \% \\
\text { BI*BA: N.S }\end{array}$ \\
\hline & & $\begin{array}{l}\text { Return on } \\
\text { assets }\end{array}$ & $\begin{array}{c}\text { Stock of } \\
\text { trademarks }\end{array}$ & $\begin{array}{c}\text { BI: } 0.051 \\
\text { BI*BA: }-0.0004\end{array}$ & $\begin{array}{c}\text { BI: } 5 \% \\
\text { BI*BA: N.S }\end{array}$ \\
\hline $\begin{array}{l}\text { Griffiths et al. } \\
\text { (2011) }\end{array}$ & Australia & Gross profit & $\begin{array}{c}\text { Stock of } \\
\text { trademarks (days) }\end{array}$ & 0.070 & $10 \%$ \\
\hline $\begin{array}{l}\text { Marco-Lajara et al. } \\
\text { (2016) }\end{array}$ & Spain & $\begin{array}{c}\text { Operating } \\
\text { income/room }\end{array}$ & $\begin{array}{c}\text { Trademark } \\
\text { dummy }\end{array}$ & 0.005 & $1 \%$ \\
\hline
\end{tabular}

* BI denotes brand-identification trademarks; BA denotes brand-awareness trademarks. N.S. stands for "not significant".

\section{The impact of trademark activities on firm survival}

General background. According to Schumpeter (1943:84), innovation is among the chief reasons for why companies survive as it "strikes not at the margins of the profits and the outputs of the existing firms but at their foundations and their very lives". An economic explanation for the existence of the exposed relationship often refers to the fact that in order to survive, a company needs to achieve the minimum efficiency scale, of course, provided that scale economies play a crucial role in the company's ability to compete in the market (Audretsch, 1991). One way to do this is by fostering innovative activities that stimulate company growth and, eventually, result in attaining the necessary level of production. As Audretsch (1991:444) puts it, "[t]hose firms which successfully innovate can expect future sales growth, while those that face only dim prospects of innovating are more likely to exit from the industry". Incumbent companies, in turn, have to continuously innovate because it reduces the threat of disruption emerging technologies may bring about (Cefis and Marsili, 2005). However, it needs to be remembered that innovation activities are inherently risky and may themselves become a source of financial distress and then market exit (Buddelmeyer et al., 2010). The diversification of product-market portfolio is another way for the company to increase its chances of survival (Srinivasan et al., 2008). When serving several industries, the company may not only hedge its exposure to demand shocks in a particular product market, but also benefit from economies of scale in marketing activities. 
At the same time, Srinivasan et al. (2008) continue, lower riskiness and the existing access to multiple markets can increase the company's visibility to potential acquirers.

Literature review. To investigate differences in survival patterns between new and incumbent companies in Australia, Jensen et al. (2008) choose to concentrate on patent and trademark applications - these are used to proxy high and low-risk innovation, respectively. As expected, the analysis largely supports the proposition that innovation activities can significantly increase the probability of firm survival. In more specific terms, trademark applications are shown to be positively associated with the likelihood that the company stays in the market, regardless of whether a new or incumbent company is being considered. A similar effect is observed for trademark holdings; yet, its magnitude for new firms is twice as large, thereby suggesting that "low-risk innovation capital is more important for new firms than incumbents" (Jensen et al., 2008:443). In a subsequent work, Buddelmeyer et al. (2010) argue that failing to account for the degree of uncertainty pertaining to each innovation measure is likely to preclude researchers from fully capturing firm survival patterns. Having this in mind, their results are still highly consistent with what was discussed before and demonstrate that the hazard rate is significantly lower for companies that file more trademark applications as well as hold larger trademark portfolios. Recognising that trademarking mainly reflects new-to-the-company innovations, the authors conclude that "the innovative activity associated with the launch of a trade mark is less risky than radically innovative activity" captured by a patent (Buddelmeyer et al., 2010:281). Finally, Helmers and Rogers (2010) generally confirm prior findings when looking at a cohort of almost 162,000 British companies. Their study reveals that patent and trademark activities increase the chances of a new company to survive in the market. They also show that survival is more difficult for companies that operate in trademark-intensive industries, which may indicate the importance of product differentiation for maintaining the competitive edge in such sectors.

In turn, Srinivasan et al. (2008) make an attempt to relate the survival chances of new companies in the U.S. high-tech industry to the diversity of their product-market portfolios. Unlike previous research, these authors focus on different options a company may face when leaving the market, including dissolution or acquisition. Furthermore, they also examine if the use of strategic resources - in this case, patents and trademarks - together with product-market diversification can enhance the company's fit with the external environment and, as such, affect its survival. The general conclusion to draw from their analysis is that "the diversity of product-market portfolio, itself, confers no advantage or disadvantage to a new high tech firm. Rather, it is important for the firm to align its productmarket strategies with the appropriate assets [...] to improve its chances of survival or acquisition" (Srinivasan et al., 2008). For example, no matter what exit option the company 
is subject to, having more trademarks enables it to survive for a longer period. This outcome supports the role of trademarks, and marketing assets in general, in improving the level and speed of cash flows, as well as highlights their potential ability to signal the company's growth strategy and, therefore, attitude towards acquisition. When a diverse product-market portfolio is matched by a larger number of trademarks, the company's exit by dissolution tends to be still delayed, while its exit by acquisition - hastened. The latter effect may suggest that such companies are perceived by rivals as a desirable target to take over.

Finally, Huang et al. (2013) look at the survival problem from a somewhat different perspective. More specifically, the authors try to understand how companies that decide to enter markets complementary to a proprietary platform can keep their returns to innovation from being appropriated by the platform owner. They focus on two types of protection mechanisms: on the one hand, intellectual property rights, such as patents and copyrights; and on the other hand, downstream capabilities - those are proxied by trademarks and consulting services. The results of their analysis suggest that an independent software vendor with a larger stock of intellectual property rights as well as with stronger downstream capabilities is more likely to join the partnership with a software platform provider. Furthermore, weaker the vendor's downstream capabilities are, stronger the influence of intellectual property rights on the probability of partnership is. Overall, the authors conclude that "[p]latforms will be less likely to grow in settings with little formal means of IP protection and, in particular, where patent and copyright protection is weak. They will be relatively more successful when [... independent vendors] are more effectively able to secure returns from their innovations through patents, copyrights, and downstream capabilities" (Huang et al., 2013:119).

\section{Other performance-related implications of trademarking}

Literature review. In addition, a few studies were identified that did not fully fit any of the above categories but still contained some valuable insights regarding performance implications of trademark activities. For example, Helmers and Rogers (2011) examine highand medium-tech start-ups in the U.K. and report that the decision to apply for a trademark is associated with subsequent asset growth. They interpret this finding as evidence that "trademarking firms are better at marketing their innovations which directly translates into higher growth" (Helmers and Rogers, 2011:1024). An analysis of small and medium enterprises operating in the Italian fashion industry conducted by Agostini et al. (2015), in turn, reveals that corporate trademarks have a positive and significant effect on sales performance. This effect tends to be persistent over time, with the benefits of trademark activities lasting for up to three years from the moment of registration. Interestingly, they find no contribution of product trademarks to the sales performance of a company. Such result seems to be 
consistent with the idea of a shorter product lifecycle in the fashion industry and, hence, a greater effort that needs to be directed at building a strong corporate brand rather than many product brands.

Trademarks are also found to have a strong impact on wages and income. Greenhalgh and Longland (2001) demonstrate that registering a new trademark is one of the key determinants of wage rises; however, there is a three-year lag before the actual effect can be observed. The authors argue that improvements in long-term profitability largely depend on the ability of a company to innovate and capture the resulting returns. So, upon the successful market introduction of a new product, which can be deduced by scrutinising trademark activities, some excess profit stemming from its sales is expected to be shared with employees through the process of wage bargaining. A work by Azomahoua and Diene (2012) considers trademarks in terms of their potential to capture certain types of innovation, especially in developing countries where other intellectual property instruments can be less accessible. Among other things, their findings show that income polarisation in African countries is significantly affected by innovation activities, but the effect very much depends on innovation origin and type. That is, they report a stronger impact on income polarisation of trademarks compared to patents when innovation is originated in the home country, while the opposite is true for non-resident innovation. 


\section{DIRECTIONS FOR FUTURE RESEARCH}

The purpose of this work has been to review the empirical literature relying on trademark statistics in order to develop a conceptual framework that brings together different research streams. First, we identified a sample of core papers that used trademark analysis while examining certain economic or business issues. Each of these papers was then classified into one of five categories, including filing determinants, product differentiation, innovation, strategic use, and firm performance. Finally, we conducted a detailed review of the selected papers and also made an attempt to position each of them with respect to other studies in the same literature stream. As a result, we have created an integrated framework that provides scholars with a better understanding of the current scope of empirical trademark research as well as helps them navigate themselves through its different areas (see Figure 4.1). In what follows, we will highlight several topics which, in our opinion, are worth further exploration.

\section{The determinants of trademark activities}

Our review suggests that when examining trademark activities, the absolute majority of authors choose to focus on either macro, country-wide factors or on industry and firmspecific aspects. At the same time, there has been growing evidence, especially in the context of the business and management literature, that intraorganisational forces also have a strong impact on how intellectual property is developed, protected, and deployed. For example, the review paper by Becheikh et al. (2006) points to the managerial perspective as being potentially useful to evaluate a company's intellectual property activities. Similarly, Hanel (2006:895) argues that intellectual property issues become "a daily preoccupation of CEOs in many industries". Other works have also emphasised the leading role of senior executives in facilitating the integrated management of intellectual property, its contribution towards forming and sustaining a company's competitive position (e.g., Reitzig, 2007; Al-Aali and Teece, 2013; Fisher and Oberholzer-Gee, 2013). Despite all these clues, there has been a general lack of research that would move the field from discussing anecdotal evidence about managerial engagement in patent and trademark activities to a systematic empirical analysis of the presumed relationship, including its effects on organisational functioning. ${ }^{4}$ This observation is particularly relevant to trademark studies: to our knowledge, there are only two empirical papers that have explicitly explored the managerial side of trademarking (see Graham and Somaya, 2006; Faurel et al., 2016). Thus, more research should be carried out to investigate the role of corporate leaders and other internal factors, such as structure and culture, in determining a company's trademarking behaviour.

\footnotetext{
${ }^{4}$ Some notable exceptions include Wu et al. (2005), Galasso and Simcoe (2011), Hirshleifer et al. (2012), and Balsmeier and Buchwald (2014).
} 


\section{The heterogeneity of trademark types}

One of the advantages of looking at different scientific fields within a single review paper is that this approach enables us to identify opportunities for cross-disciplinary learning. From what we have seen so far, it is clear that economic studies largely ignore the fact that the trademark flow tends to be heterogeneous. A rare exception to this rule is the work by Sandner and Block (2011), who hold that trademarks differ in terms of their internal value and propose a range of indicators capturing these differences. At the same time, marketing scholars are generally more aware of various trademark types and actively exploit them to examine brand strategy issues. Krasnikov et al. (2009), for example, suggest classifying all trademarks into two broad categories - trademarks that reflect a company's efforts to build brand awareness among consumers and trademarks that favour brand associations. In turn, Agostini et al. (2015) distinguish between corporate and product-related trademarks, with the former group aiming to induce customer loyalty towards the whole company. Finally, Block et al. (2014b) show that trademarks can be either independent or belong to a trademark family. What all this evidence suggests is that in order to obtain more robust results that also better match real life situations, researchers should, when it is possible, account for potential irregularities in the trademark flow, let alone try to incorporate them in hypothesis testing.

\section{The link between advertising and trademark activities}

Despite de Rassenfosse's (2017) work, systematic empirical studies that would focus on the link between a company's advertising and trademark activities are still relatively rare, especially when it comes to firm-level analysis. Meanwhile, as Fosfuri and Giarratana (2009) suggest, trademarks represent an important step in new advertising campaigns and, as such, should be regarded as a valid indicator of new advertising output. As their argument goes, by intensifying advertising activities, companies can enhance the ability of a trademark to attract new customers, with a corresponding positive effect on the company's market share. In mature product markets, advertising can assist companies with maintaining brand loyalty, which, in turn, is associated with a more inelastic demand. Overall, it appears that when advertising and trademark activities are coordinated, companies are likely to enjoy greater power in creating a differentiation advantage. Therefore, future empirical research should examine advertising in relation to a company's trademarking (or, broadly speaking, branding) strategy, including their combined effect on consumer behaviour across different markets.

\section{A wider geographical coverage}

To date, only a handful of empirical trademark studies have been devoted to developing countries, which is fairly surprising given the growing importance of their economic activities to the rest of the world. This tendency, however, is not new to 
intellectual property research, where just a quarter of all publications are concerned with a non-U.S. or Europe context (see Candelin-Palmqvist et al., 2012). Such a profound interest in developed countries may in part be justified by the greater availability and quality of their trademark data. So, once there are any breakthroughs on this front, it would be useful to gather more information about, for example, the perception of trademark protection by companies in those countries, with corresponding implications for their strategic behaviour; whether trademark valuation is significantly affected by a weaker regime of intellectual property protection pertaining to developing economies; and also what policy changes are necessary to ease the access to the protection system for different companies. Furthermore, as we have already mentioned, the geographical dimension often serves as a reliable proxy for a country's legal system. To clarify why it is so important to pay attention to the countryspecific institutional context, we should refer to the U.S. trademark system, which is jointly governed by common law, the federal legislation, and other legal acts established by the states (Cohen, 1986). With that in mind, a number of questions may arise, including how strong would the incentive for a company to apply for and maintain a trademark registration be, given that all marks are still protected under common law? What is the extent to which registration costs affect a company's trademarking behaviour in this case? Do these costs impact on the incentive to trademark for small companies compared to their larger rivals?

\section{Methodological inconsistencies}

Our review suggests that scholars tend to examine trademarks at different points of their lifecycle. For example, it has been argued that trademark applications can accurately capture new product launches, thus making them a suitable instrument for studying the Schumpeterian process of competition through innovation (Greenhalgh and Rogers, 2012). Yet, not all authors actually clarify whether those applications were eventually successful or rejected due to an invalid claim, opposition, or any other procedural reason. There are also works that do not draw a clear distinction between trademark applications and registrations, simply assuming that the lag between filing for trademark protection and its actual granting is insignificant. Meanwhile, as Graham et al. (2013) report, the average time to issuance for different U.S. trademark types can range from 0.5 to 2.5 years; but when the registration is not mandatory for legal protection, it may take more than five years for a company to have its trademark registered after the introduction in the marketplace. As for trademark stocks, there are scholars who view them as an indicator of product differentiation (Greenhalgh and Rogers, 2012). At the same time, stock and flow measures can be interchangeable when intangible assets are depreciated at a high rate (Greenhalgh and Longland, 2005). Given these inconsistencies, more research is needed to revise the existing methodology in order to enhance the validity and comparability of findings derived from trademark statistics. 


\section{Access to trademark data}

It has already been noted that one of the reasons for why empirical trademark studies are still in their infancy is because detailed trademark data are relatively difficult to obtain, unlike, for example, patents, which have been in the extensive scientific use for several decades. Moreover, a meaningful analysis of trademarks is further complicated by the need to link them to company-level financial information - and this is not a trivial task, given that there is no unique identifier to combine different datasets together (see Helmers et al., 2011). At the same time, certain improvements have recently been made that have increased the attractiveness of trademark statistics for empirical analysis. First of all, detailed trademark administrative data in the format convenient for scientific research have been released in the public domain by the USPTO (see Graham et al., 2013). The data provide a detailed account of trademark activities in the U.S. for more than a century, including useful insights into the prosecution process. Future studies should utilise these data to examine, among other things, a company's intentions when filing a new trademark application; some critical points of the registration process and their role in estimating trademark value; the trademark lifecycle and its relationship with the underlying business strategies; and the extent of a company's diversification activities. Another source of relevant statistics is the USPTO's dataset on trademark assignments, which "contains detailed information on 786,931 assignments and other transactions recorded at the USPTO between 1952 and 2013" (Marco et al., 2014:4). Researchers using this dataset may find it appealing to address the topics that are related to trademark valuation, including monetary benefits stemming from a company's reputation; the dynamics of the market for brands and its determinants; and the use of trademarks as a collateral asset. Finally, there is also an initiative to produce intellectual property statistics jointly pursued by the European Commission's Joint Research Centre and the Organisation for Economic Co-operation and Development (see Dernis et al., 2015). Their database containing intellectual property bundles for the top 2,000 corporate $R \& D$ performers worldwide can facilitate research activities on such topics as trademark filing strategies; the complementarity between patents and trademarks; and the transfer of the value originated in patents to trademarks (for the latter, see Conley et al., 2013). 
Figure 4.1. An integrated framework that brings together different streams of the empirical trademark literature

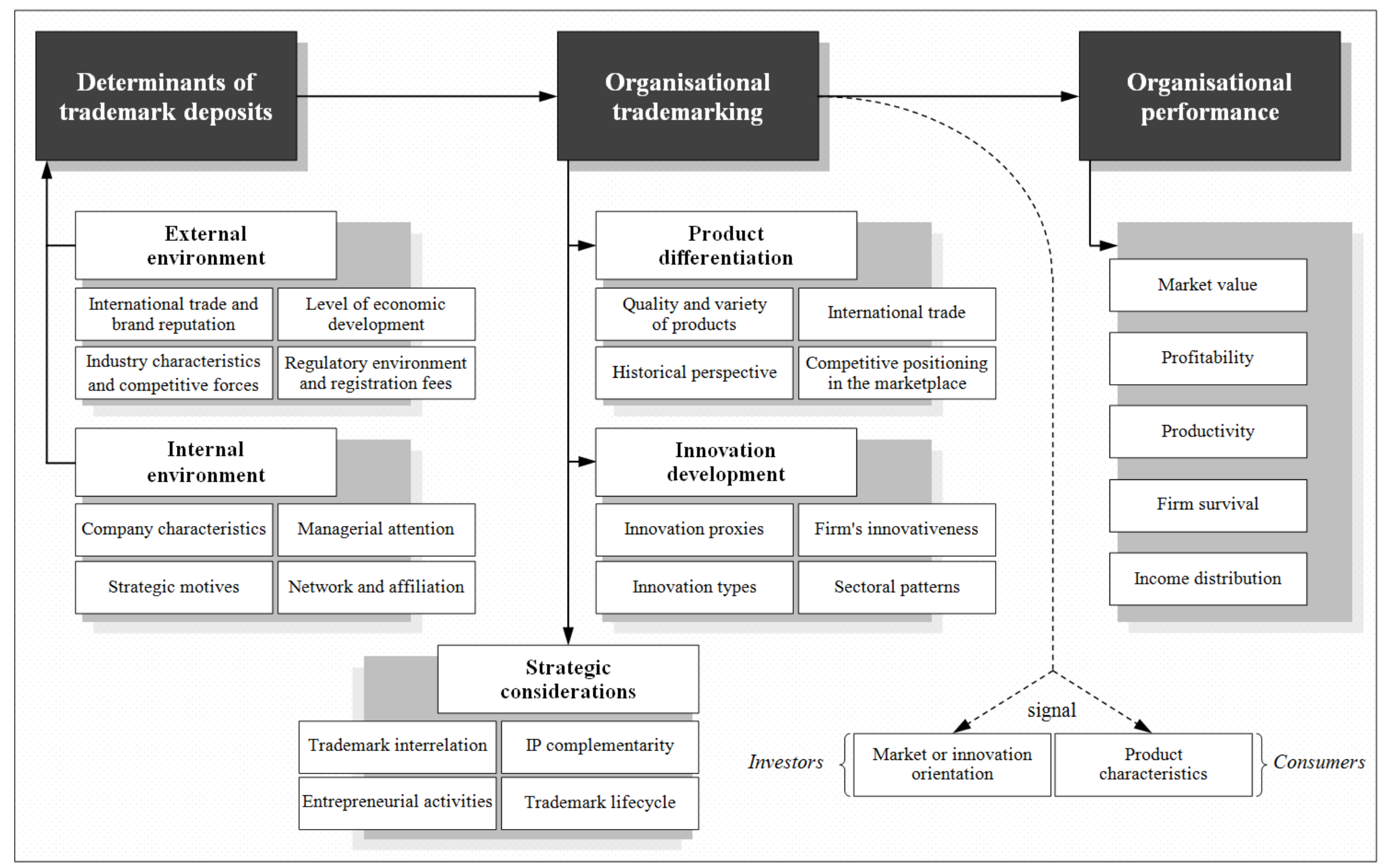




\subsection{REFERENCES}

Agostini, L., Filippini, R., and Nosella, A. (2015) Brand-building efforts and their association with SME sales performance. Journal of Small Business Management 53(S1): pp.161-173.

Aksoy-Yurdagul, D. (2015) The impact of open source software commercialization on firm value. Industry and Innovation 22(1): pp.1-17.

Al-Aali, A.Y. and Teece, D.J. (2013) Towards the (strategic) management of intellectual property: Retrospective and perspective. California Management Review 55(4): pp.1530.

Allegrezza, S. and Guarda-Rauchs, A. (1999) The determinants of trademarks deposits: An econometric investigation. Economie Appliquée 52(2): pp.51-68.

Amara, N., Landry, R., and Traoré, N. (2008) Managing the protection of innovations in knowledge-intensive business services. Research Policy 37(9): pp.1530-1547.

Audretsch, D.B. (1991) New-firm survival and the technological regime. Review of Economics and Statistics 73(3): pp.441-450.

Azomahoua, T.T. and Diene, M. (2012) Polarization patterns in economic development and innovation. Structural Change and Economic Dynamics 23(4): pp.421-436.

Bain, J.S. (1956) Barriers to new competition. Cambridge, MA: Harvard University Press.

Balsmeier, B. and Buchwald, A. (2014) Who promotes more innovations? Inside versus outside hired CEOs. Industrial and Corporate Change 24(5): pp.1013-1045.

Baroncelli, E., Fink, C., and Javorcik, B.S. (2005) The global distribution of trademarks: Some stylised facts. World Economy 28(6): pp.765-782.

Baroncelli, E., Krivonos, E., and Olarreaga, M. (2007) Trademark protection or protectionism? Review of International Economics 15(1): pp.126-145.

Becheikh, N., Landry, R., and Amara, N. (2006) Lessons from innovation empirical studies in the manufacturing sector: A systematic review of the literature from 1993-2003. Technovation 26(5): pp.644-664.

Block, J.H., De Vries, G., Schumann, J.H., and Sandner, P. (2014a) Trademarks and venture capital valuation. Journal of Business Venturing 29(4): pp.525-542.

Block, J.H., Fisch, C., and Sandner, P.G. (2014b) Trademark families: Characteristics and market values. Journal of Brand Management 21(2): pp.150-170. 
Block, J.H., Fisch, C.O., Hahn, A., and Sandner, P.G. (2015) Why do SMEs file trademarks? Insights from firms in innovative industries. Research Policy 44(10): pp.1915-1930.

Bosworth, D. and Rogers, M. (2001) Market value, R\&D and intellectual property: An empirical analysis of large Australian firms. Economic Record 77(239): pp.323-337.

Buddelmeyer, H., Jensen, P.H., and Webster, E. (2010) Innovation and the determinants of company survival. Oxford Economic Papers 62(2): pp.261-285.

Candelin-Palmqvist, H., Sandberg, B., and Mylly, U.M. (2012) Intellectual property rights in innovation management research: A review. Technovation 32(9): pp.502-512.

Castaldi, C. (2016) Trademarks, innovation and economic performances. Mimeo, The Joint Research Centre of The European Commission.

Castaldi, C. and Giarratana, M. (2011) Performance, diversification and marketing strategies: Empirical evidence from professional service firms. In: The University of Copenhagen, The DRUID Society Conference 2011, Copenhagen, Denmark 15-17 June 2011.

Cefis, E. and Marsili, O. (2005) A matter of life and death: Innovation and firm survival. Industrial and Corporate Change 14(6): pp.1167-1192.

Chamberlin, E.H. (1933) The theory of monopolistic competition: A re-orientation of the theory of value. Cambridge, MA: Harvard University Press.

Cohen, D. (1986) Trademark strategy. Journal of Marketing 50(1): pp.61-74.

Conley, J.G., Bican, P.M., and Ernst, H. (2013) Value articulation: A framework for the strategic management of intellectual property. California Management Review 55(4): pp.102-120.

Crass, D. (2014a) Which firms use trademarks - and why? Representative firm-level evidence from Germany. ZEW Discussion Paper Series no. 14-118. Mannheim, Germany: ZEW.

Crass, D. (2014b) The impact of brand use on innovation performance - Empirical results for Germany. ZEW Discussion Paper Series no. 14-119. Mannheim, Germany: ZEW.

Crass, D. and Schwiebacher, F. (2013) Do trademarks diminish the substitutability of products in innovative knowledge-intensive services? ZEW Discussion Paper Series no. 13-061. Mannheim, Germany: ZEW.

Crass, D. and Schwiebacher, F. (2017) The importance of trademark protection for product differentiation and innovation. Journal of Industrial and Business Economics - 
Economia e Politica Industriale 44(2): pp.199-220.

Crass, D., Czarnitzki, D., and Toole, A.A. (2016) The dynamic relationship between investments in brand equity and firm profitability: Evidence using trademark registrations. USPTO Economic Working Papers Series no. 2016-1. Alexandria, VA: USPTO.

da Silva Lopes, T. and Guimaraes, P. (2014) Trademarks and British dominance in consumer goods, 1876-1914. Economic History Review 67(3): pp.793-817.

de Rassenfosse, G. (2015) On the price elasticity of demand for trademarks. Institute for Technology and Public Policy Working Paper Series no. 1. Lausanne, Switzerland: EPFL.

de Rassenfosse, G. (2017) An assessment of how well we account for intangibles. Industrial and Corporate Change 26(3): pp.517-534.

De Vries, G., Pennings, E., Block, J.H., and Fisch, C. (2017) Trademark or patent? The effects of market concentration, customer type and venture capital financing on start-ups' initial IP applications. Industry and Innovation 24(4): pp.325-345.

Dernis H., Dosso M., Hervás F., Millot V., Squicciarini M., and Vezzani A. (2015) World corporate top R\&D investors: Innovation and IP bundles. JRC and OECD Common Report. Luxembourg: Publications Office of the European Union.

Doh, S. and Kim, B. (2014) Government support for SME innovations in the regional industries: The case of government financial support program in South Korea. Research Policy 43(9): pp.1557-1569.

Duguid, P., da Silva Lopes, T., and Mercer, O (2010) Reading registrations: An overview of 100 years of trade mark registrations in France, the United Kingdom and the United States. In: da Silva Lopes, T. and Duguid, P. (Eds.) Trademarks, brands, and competitiveness. New York, NY: Routledge, pp.9-30.

Duygun, M., Sena, V., and Shaban, M. (2013) Schumpeterian competition and efficiency among commercial banks. Journal of Banking and Finance 37(12): pp.5176-5185.

Duygun, M., Sena, V., and Shaban, M. (2014) Trademarking status and economic efficiency among commercial banks: Some evidence for the UK. Journal of Banking and Finance 49(December): pp.506-514.

Duygun, M., Sena, V., and Shaban, M. (2016) Trademarking activities and total factor productivity: Some evidence for British commercial banks using a metafrontier approach. Journal of Banking and Finance 72(Supplement/November): pp.S70-S80. 
Economides, N.S. (1988) The economics of trademarks. Trademark Reporter 78(4): pp.523-539.

Farooqui, S., Goodridge, P., and Haskel, J. (2011) The role of intellectual property rights in the UK market sector. IPO Reports no. 2011/2. Newport, UK: Intellectual Property Office.

Faurel, L., Li, Q., Shanthikumar, D.M., and Teoh, S.H. (2016) CEO incentives and new product development: Insights from trademarks. Mimeo, The University of California, Irvine.

Feeny, S. and Rogers, M. (2003) Innovation and performance: Benchmarking Australian firms. Australian Economic Review 36(3): pp.253-264.

Fink, C., Helmers, C., and Ponce, C. (2014) Trademarks squatters: Evidence from Chile. Economic Research Working Papers no. 22. Geneva: WIPO.

Fink, C., Javorcik, B.S., and Spatareanu, M. (2005) Income-related biases in international trade: What do trademark registration data tell us? Review of World Economics 141(1): pp.79-103.

Fisher III, W.W. and Oberholzer-Gee, F. (2013) Strategic management of intellectual property: An integrated approach. California Management Review 55(4): pp. 157-183.

Flikkema, M., Castaldi, C., De Man, A.-P., and Seip, M. (2015) Explaining the trademarkinnovation linkage: The role of patents and trademark filing strategies. In: LUISS, The DRUID Society Conference 2015, Rome, Italy 15-17 June 2015.

Flikkema, M., De Man, A.P., and Castaldi, C. (2014) Are trademark counts a valid indicator of innovation? Results of an in-depth study of new Benelux trademarks filed by SMEs. Industry and Innovation 21(4): pp.310-331.

Flikkema, M.J., De Man, A.-P., and Wolters, M.J.J. (2010) New trademark registration as an indicator of innovation: Results of an explorative study of Benelux trademark data. Research Memorandum no. 2010-9. Amsterdam: University of Amsterdam.

Fosfuri, A. and Giarratana, M.S. (2009) Masters of war: Rivals' product innovation and new advertising in mature product markets. Management Science 55(2): pp.181-191.

Galasso, A. and Simcoe, T.S. (2011) CEO overconfidence and innovation. Management Science 57(8): pp.1469-1484.

Gallié, E.P. and Legros, D. (2012) French firms' strategies for protecting their intellectual property. Research Policy 41(4): pp.780-794. 
Gallouj, F. and Weinstein, O. (1997) Innovation in services. Research Policy 26(4-5): pp.537-556.

Gambardella, A. and Giarratana, M.S. (2006) Innovations for products, innovations for licensing: Patents and downstream assets in the software security industry. Mimeo.

Gao, G. and Hitt, L.M. (2012) Information technology and trademarks: Implications for product variety. Management Science 58(6): pp.1211-1226.

Goel, R.K., Saunoris, J.W., and Zhang, X. (2016) Intranational and international knowledge flows: Effects on the formal and informal sectors. Contemporary Economic Policy 34(2): pp.297-311.

González-Pedraz, C. and Mayordomo, S. (2012) Trademark activity and the market performance of U.S. commercial banks. Journal of Business Economics and Management 13(5): pp.931-950.

Gotsch, M. and Hipp, C. (2012) Measurement of innovation activities in the knowledgeintensive services industry: A trademark approach. Service Industries Journal 32(13): pp.2167-2184.

Gotsch, M. and Hipp, C. (2014) Using trademarks to measure innovation in knowledgeintensive business services. Technology Innovation Management Review 4(5): pp.1830.

Graham, S., Hancock, G., Marco, A., and Myers, A.F. (2013) The USPTO trademark case files dataset: Descriptions, lessons, and insights. Alexandria, VA: USPTO.

Graham, S.J. and Somaya, D. (2006) Vermeers and rembrandts in the same attic: Complementarity between copyright and trademark leveraging strategies in software. GER Working Paper Series. Atlanta, GA: Georgia Institute of Technology.

Greenhalgh, C. and Longland, M. (2001) Intellectual property in UK firms: Creating intangible assets and distributing the benefits via wages and jobs. Oxford Bulletin of Economics and Statistics 63(S1): pp.671-696.

Greenhalgh, C. and Longland, M. (2005) Running to stand still? - The value of R\&D, patents and trade marks in innovating manufacturing firms. International Journal of the Economics of Business 12(3): pp.307-328.

Greenhalgh, C. and Rogers, M. (2006a) Market value of UK intellectual property: Manufacturing, utility and financial service firms. In: Bosworth, D. and Webster, E. (Eds.) The management of intellectual property. Cheltenham, UK: Edward Elgar, pp.132-145. 
Greenhalgh, C. and Rogers, M. (2006b) The value of innovation: The interaction of competition, R\&D and IP. Research Policy 35(4): pp.562-580.

Greenhalgh, C. and Rogers, M. (2008) Intellectual property activity by service sector and manufacturing firms in the UK, 1996-2000. In: Scarborough, H. (Ed.) The evolution of business knowledge. New York, NY: Oxford University Press, pp. 295-314.

Greenhalgh, C. and Rogers, M. (2012) Trade marks and performance in services and manufacturing firms: Evidence of Schumpeterian competition through innovation. Australian Economic Review 45(1): pp.50-76.

Greenhalgh, C., Rogers, M., Schautschick, P., and Sena, V. (2012) Trade mark incentives. IPO Reports no. 2011/1. Newport, UK: Intellectual Property Office.

Griffiths, W. and Webster, E. (2006) Trends in the market valuation of Australian intellectual property. In: Bosworth, D. and Webster, E. (Eds.) The management of intellectual property. Cheltenham, UK: Edward Elgar, pp.146-158.

Griffiths, W., Jensen, P.H., and Webster, E. (2011) What creates abnormal profits? Scottish Journal of Political Economy 58(3): pp.323-346.

Griliches, Z. (1981) Market value, R\&D, and patents. Economics Letters 7(2): pp.183-187.

Hall, B.H. (1999) Innovation and market value. NBER Working Paper Series no. 6984. Cambridge, MA: NBER.

Hall, B.H., Helmers, C., Rogers, M., and Sena, V. (2013) The importance (or not) of patents to UK firms. Oxford Economic Papers 65(3): pp.603-629.

Hall, R. (1992) The strategic analysis of intangible resources. Strategic Management Journal 13(2): pp.135-144.

Hanel, P. (2006) Intellectual property rights business management practices: A survey of the literature. Technovation 26(8): pp.895-931.

Heald, P.J. and Brauneis, R. (2010) The myth of Buick Aspirin: An empirical study of trademark dilution by product and trade names. Cardozo Law Review 32(4): pp.25332578.

Heath, D. and Mace, C. (2017) What's a brand worth? Trademark protection, profits and product quality. Mimeo.

Helmers, C. and Rogers, M. (2010) Innovation and the survival of new firms in the UK. Review of Industrial Organization 36(3): pp.227-248.

Helmers, C. and Rogers, M. (2011) Does patenting help high-tech start-ups? Research 
Policy 40(7): pp.1016-1027.

Helmers, C. and Schautschick, P. (2013) The use of intellectual property right bundles by

firms in the UK. IPO Reports no. 2013/28. Newport, UK: Intellectual Property Office.

Helmers, C., Rogers, M., and Schautschick, P. (2011) Intellectual property at the firmlevel in the UK: The Oxford firm-level intellectual property database. Department of Economics Discussion Paper Series no. 546. Oxford: The University of Oxford.

Helmers, C., von Graevenitz, G., Greenhalgh, C., Guceri, I., and Schautschick, P. (2013)

Intellectual property rights and high-growth firms in the UK. IPO Reports no. 2013/27. Newport, UK: Intellectual Property Office.

Herz, B. and Mejer, M. (2016) On the fee elasticity of the demand for trademarks in Europe. Oxford Economic Papers 68(4): pp.1039-1061.

Hipp, C. and Grupp, H. (2005) Innovation in the service sector: The demand for servicespecific innovation measurement concepts and typologies. Research Policy 34(4): pp.517-535.

Hirshleifer, D., Low, A., and Teoh, S.H. (2012) Are overconfident CEOs better innovators? Journal of Finance 67(4): pp.1457-1498.

Huang, P., Ceccagnoli, M., Forman, C., and Wu, D.J. (2013) Appropriability mechanisms and the platform partnership decision: Evidence from enterprise software. Management Science 59(1): pp.102-121.

Jensen, P.H. and Webster, E. (2004) Patterns of trademarking activity in Australia. Australian Intellectual Property Journal 15(2): pp.112-126.

Jensen, P.H. and Webster, E. (2006) Firm size and the use of intellectual property rights. Economic Record 82(256): pp.44-55.

Jensen, P.H. and Webster, E. (2008) Labelling characteristics and demand for retail grocery products in Australia. Australian Economic Papers 47(2): pp.129-140.

Jensen, P.H. and Webster, E. (2009) Another look at the relationship between innovation proxies. Australian Economic Review 48(3): pp.252-269.

Jensen, P.H., Webster, E., and Buddelmeyer, H. (2008) Innovation, technological conditions and new firm survival. Economic Record 84(267): pp.434-448.

Krasnikov, A., Mishra, S., and Orozco, D. (2009) Evaluating the financial impact of branding using trademarks: A framework and empirical evidence. Journal of Marketing 73(6): pp.154-166. 
Landes, W.M. and Posner, R.A. (1987) Trademark law: An economic perspective. Journal of Law and Economics 30(2): pp.265-309.

Lechner, C., Lorenzoni, G., and Tundis, E. (2016) Vertical disintegration of production and the rise of market for brands. Journal of Business Venturing Insights 6(December): pp.1-6.

Llerena, P. and Millot, V. (2013) Are trade marks and patents complementary or substitute protections for innovation? Document de Travail no. 2013-01. Strasbourg, France: BETA.

Llonch-Casanovas, M. (2012) Trademarks, product differentiation and competitiveness in the Catalan knitwear districts during the twentieth century. Business History 54(2): pp.179-200.

Mainwaring, L., Moore, N., and Murphy, P. (2004) Trademark holdings of production firms in Britain and Ireland. Mimeo, Swansea University.

Malmberg, C. (2005) Trademarks statistics as innovation indicator? - A micro study. CIRCLE Working Paper Series no. 2005/17. Lund, Sweden: CIRCLE.

Mangàni, A. (2006) An economic analysis of rise of service marks. Journal of Intellectual Property Rights 11(4): pp.249-259.

Mangàni, A. (2007) Measuring variety and quality of products with trademarks. International Economic Journal 21(4): pp.613-631.

Marco, A., Myers, A.F., Graham, S., and Apple, K. (2014) The USPTO trademark assignment dataset: Descriptions and insights. USPTO Economic Working Papers Series no. 2014-2. Alexandria, VA: USPTO.

Marco-Lajara, B., del Carmen Zaragoza-Sáez, P., Claver-Cortés, E., and Úbeda-García, M. (2016) Knowledge sources, agglomeration, and hotel performance. Journal of Business Research 69(11): pp.4856-4861.

Melnyk, V., Giarratana, M., and Torres, A. (2014) Marking your trade: Cultural factors in the prolongation of trademarks. Journal of Business Research 67(4): pp.478-485.

Mendonça, S., Pereira, T.S., and Godinho, M.M. (2004) Trademarks as an indicator of innovation and industrial change. Research Policy 33(9): pp.1385-1404.

Millot, V. (2009) Trademarks as an indicator of product and marketing innovations. OECD STI Working Paper Series no. 2009/06. Paris: OECD.

Millot, V. (2011) Firms' intangible assets: Who relies on trademarks? Analysis of French and 
German firms' trademarking behaviour. In: The University of Copenhagen, The DRUID Society Conference 2011, Copenhagen, Denmark 15-17 June 2011.

Munari, F. and Santoni, S. (2009) Exploiting complementarities in IPR mechanisms: The joint use of patents, trademarks and designs by SMEs. In: The University of Bologna, The $4^{\text {th }}$ Annual Conference of the EPIP Association, Bologna, Italy 24-25 September 2009.

Rao, V.R., Agarwal, M.K., and Dahlhoff, D. (2004) How is manifest branding strategy related to the intangible value of a corporation? Journal of Marketing 68(4): pp.126141.

Reitzig, M. (2007) How executives can enhance IP strategy and performance. MIT Sloan Management Review 49(1): pp.37-43.

Sandner, P.G. (2009) The identification of trademark filing strategies: Creating, hedging, modernizing, and extending brands. Trademark Reporter 99(5): pp.1257-1298.

Sandner, P.G. and Block, J. (2011) The market value of R\&D, patents, and trademarks. Research Policy 40(7): pp.969-985.

Schautschick, P. and Greenhalgh, C. (2016) Empirical studies of trade marks - The existing economic literature. Economics of Innovation and New Technology 25(4): pp.358-390.

Schmoch, U. (2003) Service marks as novel innovation indicator. Research Evaluation 12(2): pp.149-156.

Schmoch, U. and Gauch, S. (2009) Service marks as indicators for innovation in knowledgebased services. Research Evaluation 18(4): pp.323-335.

Schumpeter, J.A. (1943) Capitalism, socialism and democracy. London: George Allen and Unwin Ltd.

Semadeni, M. (2006) Minding your distance: How management consulting firms use service marks to position competitively. Strategic Management Journal 27(2): pp.169-187.

Semadeni, M. and Anderson, B.S. (2010) The follower's dilemma: Innovation and imitation in the professional services industry. Academy of Management Journal 53(5): pp.11751193.

Squicciarini, M., Millot, V., and Dernis, H. (2012) Universities' trademark patterns and possible determinants. Economics of Innovation and New Technology 21(5/6): pp.473504.

Srinivasan, R., Lilien, G.L., and Rangaswamy, A. (2008) Survival of high tech firms: The 
effects of diversity of product-market portfolios, patents, and trademarks. International Journal of Research in Marketing 25(2): pp.119-128.

Tancs, L.A. (2009) Understanding trademark law: A beginner's guide. New York: Oxford University Press.

Teece, D.J. (1986) Profiting from technological innovation: Implications for integration, collaboration, licensing and public policy. Research Policy 15(6): pp.285-305.

The Trademark Act of 1946, Pub. L. No. 79-489, 50 Stat. 427 (July 5, 1946), codified, as amended, at 15 U.S.C. 1051 et seq.

The Trademark Law Revision Act of 1988, Pub. L. No. 100-667, 102 Stat. 3935 (November 16, 1988), amending 15 U.S.C. 1051 et seq.

von Graevenitz, G. (2009) Which reputations does a brand owner need? Evidence from trade mark opposition. In: The University of Southern California, The $4^{\text {th }}$ Annual Conference on Empirical Legal Studies, Los Angeles, California, U.S. 20-21 November 2009.

von Graevenitz, G. (2013) Trade mark cluttering - Evidence from EU enlargement. Oxford Economic Papers 65(3): pp.721-745.

von Graevenitz, G., Greenhalgh, C., Helmers, C., and Schautschick, P. (2012) Trade mark cluttering: An exploratory report. IPO Reports no. 2012/11. Newport, UK: Intellectual Property Office.

WIPO (2013) World intellectual property report: Brands - Reputation and image in the global marketplace. WIPO Economics and Statistics Series no. 944E/2013. Geneva: WIPO.

Wu, S., Levitas, E., and Priem, R.L. (2005) CEO tenure and company invention under differing levels of technological dynamism. Academy of Management Journal 48(5): pp.859-873.

Zhou, H., Sandner, P.G., Martinelli, S.L., and Block, J.H. (2016) Patents, trademarks, and their complementarity in venture capital funding. Technovation 47(January): pp.14-22. 
APPENDIX A. SUMMARY TABLES

Table A.1. Papers on the determinants of trademark deposits

\begin{tabular}{|c|c|c|c|c|}
\hline Paper & Geographical scope & Period & Sample description & Sources of IP statistics \\
\hline \multicolumn{5}{|c|}{ The effect of external environment on trademark deposits } \\
\hline Jensen and Webster (2004) & Australia & $1906-2002$ & Australian firms & IP Australia \\
\hline Baroncelli et al. (2005) & Multi-country analysis & 1994-1998 & $\sim 100$ countries & WIPO \\
\hline Mangàni (2006) & Multi-country analysis & $1995-2006$ & 110 countries & OHIM, IP Australia, Italian PTO \\
\hline Herz and Mejer (2016) & Multi-country analysis & $1993-2011$ & 22 EU countries & OHIM \\
\hline De Vries et al. (2017) & U.S. & $1998-2007$ & 4,703 companies & USPTO \\
\hline \multicolumn{5}{|c|}{ The effect of internal environment on trademark deposits } \\
\hline Allegrezza and Guarda-Rauchs (1999) & Benelux countries & 1999 & $\sim 2,500$ firms & Benelux Office for IP \\
\hline Jensen and Webster (2006) & Australia & $1989-2001$ & 490 observations & IP Australia \\
\hline Gao and Hitt (2012) & Fortune 1000 manufact. firms & $1987-1997$ & 116 firms & USPTO \\
\hline Block et al. (2015) & U.S. & 2012 & 600 firms & Online Survey \\
\hline de Rassenfosse (2017) & Multi-country analysis & $1980-2010$ & 32 countries & WIPO, Benelux Office for IP \\
\hline \multicolumn{5}{|c|}{ Other determinants of trademark deposits } \\
\hline Squicciarini et al. (2012) & U.S. & $1997-2007$ & 621 universities & USPTO, EPO \\
\hline Doh and Kim (2014) & South Korea & 2004-2009 & 47 firms & Korea IPR Information Service \\
\hline
\end{tabular}

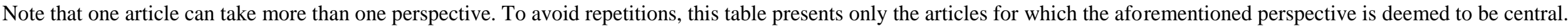


Table A.2. Papers on the use of trademarks as an indicator of product differentiation

\begin{tabular}{|c|c|c|c|c|}
\hline Paper & Geographical scope & Period & Sample description & Sources of IP statistics \\
\hline \multicolumn{5}{|c|}{ Product differentiation in international trade } \\
\hline Fink et al. (2005) & Multi-country analysis & 1994-1998 & $\sim 100$ countries & WIPO \\
\hline Baroncelli et al. (2007) & Multi-country analysis & 1994-1998 & 4 countries & WIPO \\
\hline Mangàni (2007) & Multi-country analysis & 2003 & $\sim 120$ countries & OHIM \\
\hline \multicolumn{5}{|l|}{ Competitive positioning } \\
\hline Semadeni (2006) & U.S. & 1989-1999 & 50 consulting firms & USPTO \\
\hline Semadeni and Anderson (2010) & U.S. & 1989-1999 & 50 consulting firms & USPTO \\
\hline Crass and Schwiebacher (2017) & Germany & 2011 & 4,453 firms & German Innovation Survey \\
\hline \multicolumn{5}{|c|}{ Historical studies of product differentiation } \\
\hline Llonch-Casanovas (2012) & Spain & $1865-1996$ & Knitwear industry & Spanish PTO \\
\hline da Silva Lopes and Guimaraes (2014) & U.K. & $1876-1914$ & Light consumer goods industries & IPO \\
\hline
\end{tabular}

Note that one article can take more than one perspective. To avoid repetitions, this table presents only the articles for which the aforementioned perspective is deemed to be central. 
Table A.3. Papers on the use of trademarks as an indicator of innovation

\begin{tabular}{|c|c|c|c|c|}
\hline Paper & Geographical scope & Period & Sample description & Sources of IP statistics \\
\hline \multicolumn{5}{|c|}{ The use of service marks and innovation in the service sector } \\
\hline Schmoch (2003) & Germany & 2001 & 377 firms & Centre of EU Economic Research \\
\hline Schmoch and Gauch (2009) & Multi-country analysis & $1990-2008$ & 12 countries & Questel Orbit \\
\hline Gotsch and Hipp (2012) & Germany & 2009 & 278 firms & Online Survey \\
\hline Gotsch and Hipp (2014) & Germany & 2009 & 278 firms & Online Survey \\
\hline \multicolumn{5}{|c|}{ Links to other indicators of innovation } \\
\hline Mendonça et al. (2004) & Multi-country analysis & 1996-2002 & 15 EU countries, incl. Portugal & OHIM, INPI \\
\hline Hanel (2008) & Canada & 1997-1999 & 5,220 firms & Statistics Canada Innovation Survey \\
\hline Jensen and Webster (2009) & Australia & 2001-2007 & 1,400 firm-level observations & IP Australia \\
\hline Hall et al. (2013) & U.K. & 1998-2006 & 8,577 firms & IPO, EPO, OHIM \\
\hline Flikkema et al. (2014) & Benelux countries & $2007-2008$ & 660 firms & Benelux Office for IP \\
\hline
\end{tabular}

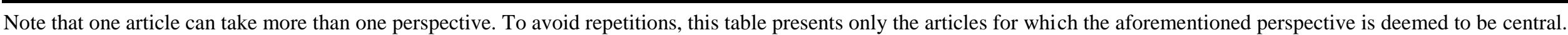


Table A.4. Papers on trademark-based strategies

\begin{tabular}{|c|c|c|c|c|}
\hline Paper & Geographical scope & Period & Sample description & Sources of IP statistics \\
\hline \multicolumn{5}{|c|}{ Trademarks in relation to each other } \\
\hline Sandner (2009) & Multi-country analysis & 1996-2004 & 2,289 firms & OHIM \\
\hline von Graevenitz (2013) & E.U. & $1997-2010$ & 597,450 application events & OHIM \\
\hline Block et al. (2014b) & Multi-country analysis & 2004 & 1,735 firms & OHIM \\
\hline \multicolumn{5}{|c|}{ Trademarks in relation to other intellectual property rights } \\
\hline Amara et al. (2008) & Canada & 2003 & 2,625 establishments & Statistics Canada Innovation Survey \\
\hline Gallié and Legros (2012) & France & 2001-2004 & 3,547 firms with IPRs & Community Innovation Survey \\
\hline \multicolumn{5}{|c|}{ Trademarks and entrepreneurial activities } \\
\hline Goel et al. (2016) & Multicountry analysis & 2001-2010 & 52 countries & World Development Indicators \\
\hline Lechner et al. (2016) & U.S. & $1975-2005$ & Manufacturing industry & USPTO \\
\hline \multicolumn{5}{|l|}{ Trademark lifecycle } \\
\hline Jensen and Webster (2008) & Australia & $2002-2005$ & 92 brands & IP Australia \\
\hline Melnyk et al. (2014) & U.S. & $1993-2000$ & 87 software firms & USPTO \\
\hline
\end{tabular}

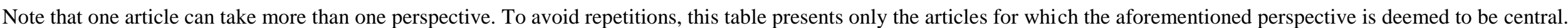


Table A.5. Papers on performance implications of trademark activities

\begin{tabular}{|c|c|c|c|c|}
\hline Paper & Geographical scope & Period & Sample description & Sources of IP statistics \\
\hline \multicolumn{5}{|c|}{ Market value gains from trademarking } \\
\hline Bosworth and Rogers (2001) & Australia & 1994-1996 & 60-120 firms & IP Australia \\
\hline Feeny and Rogers (2003) & Australia & $1995-1998$ & 249-369 firms & IP Australia \\
\hline Greenhalgh and Rogers (2006b) & U.K. & $1989-2002$ & 619 firms & IPO, EPO, Marquesa Search Systems \\
\hline Fosfuri and Giarratana (2009) & U.S. & $1999-2003$ & Coca-Cola and Pepsi & USPTO \\
\hline Krasnikov et al. (2009) & U.S. & $1995-2005$ & 108 firms & USPTO \\
\hline Sandner and Block (2011) & Multicountry analysis & $1996-2002$ & 1,216 firms & EPO, OHIM \\
\hline González-Pedraz and Mayordomo (2012) & U.S. & $1996-2006$ & 16 commercial banks & USPTO \\
\hline Greenhalgh and Rogers (2012) & U.K. & $1996-2000$ & 1,600 firms & Oxford IP Research Centre \\
\hline Block et al. (2014a) & U.S. & $1998-2007$ & 2,341 firms & USPTO, EPO \\
\hline Aksoy-Yurdagul (2015) & Fortune Global 500 List & 2003-2009 & 70 firms & USPTO \\
\hline Zhou et al. (2016) & U.S. & $2000-2012$ & 299 firms & USPTO, EPO \\
\hline \multicolumn{5}{|c|}{ Productivity gains from trademarking } \\
\hline Greenhalgh and Longland (2005) & U.K. & $1988-1994$ & 740 firms & Marquesa Search Systems \\
\hline Duygun et al. (2016) & U.K. & $2005-2013$ & 330 banks & IPO, OHIM \\
\hline \multicolumn{5}{|c|}{ Profitability gains from trademarking } \\
\hline Griffiths et al. (2011) & Australia & $1990-2006$ & 2,689 firms & IP Australia \\
\hline Duygun et al. (2013) & U.K. & 2001-2012 & 20 banks & IPO, Marquesa Search Systems \\
\hline
\end{tabular}




\begin{tabular}{|c|c|c|c|c|}
\hline Duygun et al. (2014) & U.K. & $2001-2013$ & 213 observations & IPO, OHIM \\
\hline Marco-Lajara et al. (2016) & Spain & $2009-2013$ & 2,003 firms in the hotel industry & SdA Balances Ibéricos \\
\hline \multicolumn{5}{|c|}{ The impact of trademark activities on firm survival } \\
\hline Jensen et al. (2008) & Australia & $1997-2005$ & 261,510 firms & IP Australia \\
\hline Srinivasan et al. (2008) & U.S. & 1993-2002 & 1,435 high-tech firms & USPTO \\
\hline Buddelmeyer et al. (2010) & Australia & $1997-2003$ & 299,038 firms & IP Australia \\
\hline Helmers and Rogers (2010) & U.K. & $2001-2005$ & 161,857 firms & IPO, EPO, Marquesa Search Systems \\
\hline Huang et al. (2013) & U.S. & $1996-2004$ & 1,220 software firms & USPTO \\
\hline \multicolumn{5}{|c|}{ Other performance-related implications of trademarking } \\
\hline Greenhalgh and Longland (2001) & U.K. & $1986-1995$ & 700 firms & IPO, EPO, USPTO, WIPO \\
\hline Helmers and Rogers (2011) & U.K. & $2000-2005$ & 7,038 firms & IPO, EPO, Marquesa Search Systems \\
\hline Azomahoua and Diene (2012) & Multicountry analysis & $1960-2008$ & 34 countries & World Bank Africa Database \\
\hline Agostini et al. (2015) & Italy & 2008-2012 & 133 firms in the fashion industry & Italian PTO \\
\hline
\end{tabular}

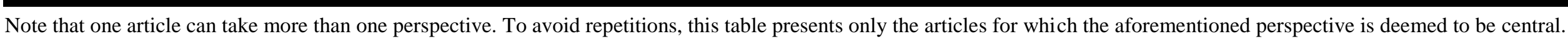


Table A.6. An overview of other contributions to the empirical trademark literature

\begin{tabular}{|c|c|c|c|c|}
\hline Paper & $\begin{array}{c}\text { Brief } \\
\text { description }\end{array}$ & $\begin{array}{l}\text { Geographical } \\
\text { scope }\end{array}$ & Period & $\begin{array}{l}\text { Source of } \\
\text { IP data }\end{array}$ \\
\hline \multicolumn{5}{|c|}{ Working papers and conference proceedings } \\
\hline $\begin{array}{l}\text { Mainwaring et al. } \\
\text { (2004) }\end{array}$ & $\begin{array}{l}\text { Determinants of trademark } \\
\text { deposits and regional } \\
\text { disparities }\end{array}$ & UK, Ireland & $1983-2001$ & IPO \\
\hline $\begin{array}{l}\text { Malmberg } \\
(2005)\end{array}$ & $\begin{array}{l}\text { The use of trademark } \\
\text { statistics as an indicator of } \\
\text { new-to-the-firm innovations }\end{array}$ & Sweden & $1935-2000$ & $\begin{array}{c}\text { PRV Svensk } \\
\text { Varumärkestidning }\end{array}$ \\
\hline $\begin{array}{l}\text { Gambardella and Giarratana } \\
(2006)\end{array}$ & $\begin{array}{l}\text { The effect of downstream } \\
\text { assets on new product } \\
\text { launches }\end{array}$ & U.S. & $1993-2000$ & USPTO \\
\hline $\begin{array}{l}\text { Graham and Somaya } \\
(2006)\end{array}$ & $\begin{array}{l}\text { The complementarity } \\
\text { between different } \\
\text { intellectual property rights }\end{array}$ & U.S. & 1985-1999 & $\begin{array}{l}\text { Federal Judicial } \\
\text { Centre }\end{array}$ \\
\hline $\begin{array}{l}\text { Millot } \\
(2009)\end{array}$ & $\begin{array}{l}\text { Statistical properties of } \\
\text { trademarks and a potential } \\
\text { link to innovations }\end{array}$ & $\begin{array}{l}\text { Multi-country } \\
\text { analysis }\end{array}$ & $1884-2007$ & $\begin{array}{l}\text { USPTO, } \\
\text { OHIM, JPO }\end{array}$ \\
\hline $\begin{array}{l}\text { Munari and Santoni } \\
\text { (2009) }\end{array}$ & $\begin{array}{l}\text { The complementarity } \\
\text { between patents, trademarks, } \\
\text { and designs }\end{array}$ & Italy & 2004-2007 & $\begin{array}{l}\text { EPO, OHIM, } \\
\text { Italian PTO }\end{array}$ \\
\hline $\begin{array}{l}\text { von Graevenitz } \\
\text { (2009) }\end{array}$ & $\begin{array}{l}\text { The defence of trademarks } \\
\text { through opposition at a } \\
\text { trademark office }\end{array}$ & $\begin{array}{l}\text { Multi-country } \\
\text { analysis }\end{array}$ & 1996-2004 & OHIM \\
\hline $\begin{array}{l}\text { Flikkema et al. } \\
\text { (2010) }\end{array}$ & $\begin{array}{l}\text { The extent to which new } \\
\text { trademarks refer to } \\
\text { innovations }\end{array}$ & $\begin{array}{l}\text { Benelux } \\
\text { countries }\end{array}$ & 2007-2008 & Benelux Office for IP \\
\hline $\begin{array}{l}\text { Castaldi and Giarratana } \\
\text { (2011) }\end{array}$ & $\begin{array}{l}\text { The determinants of firm } \\
\text { performance in professional } \\
\text { services }\end{array}$ & U.S. & 2000-2009 & USPTO \\
\hline $\begin{array}{l}\text { Millot } \\
(2011)\end{array}$ & $\begin{array}{l}\text { Companies' trademarking } \\
\text { behaviour, a link to } \\
\text { innovation }\end{array}$ & $\begin{array}{l}\text { France, } \\
\text { Germany }\end{array}$ & 1999-2006 & $\begin{array}{l}\text { INPI France, DPMA, } \\
\text { OHIM, EPO }\end{array}$ \\
\hline $\begin{array}{l}\text { Crass and Schwiebacher } \\
\text { (2013) }\end{array}$ & $\begin{array}{l}\text { The effect of trademarks on } \\
\text { product substitutability and } \\
\text { imitability }\end{array}$ & Germany & 2010 & $\begin{array}{l}\text { Mannheim } \\
\text { Innovation Panel }\end{array}$ \\
\hline $\begin{array}{l}\text { Llerena and Millot } \\
\text { (2013) }\end{array}$ & $\begin{array}{l}\text { The complementarity } \\
\text { between patents and } \\
\text { trademarks }\end{array}$ & France & $1998-2007$ & $\begin{array}{l}\text { OHIM, } \\
\text { INPI France }\end{array}$ \\
\hline $\begin{array}{l}\text { Crass } \\
(2014 a)\end{array}$ & $\begin{array}{l}\text { Firm characteristics and } \\
\text { their role in driving } \\
\text { trademark registrations }\end{array}$ & Germany & 2010 & $\begin{array}{l}\text { OHIM, } \\
\text { DPMA }\end{array}$ \\
\hline $\begin{array}{l}\text { Crass } \\
(2014 b)\end{array}$ & $\begin{array}{l}\text { The role of brand use in the } \\
\text { commercial success of } \\
\text { product innovations }\end{array}$ & Germany & 2010 & $\begin{array}{l}\text { OHIM, } \\
\text { DPMA }\end{array}$ \\
\hline $\begin{array}{l}\text { Fink et al. } \\
(2014)\end{array}$ & $\begin{array}{l}\text { Trademark squatting and its } \\
\text { effect on a company's } \\
\text { strategic behaviour }\end{array}$ & Chile & 1991-2010 & INAPI \\
\hline
\end{tabular}




\begin{tabular}{|c|c|c|c|c|}
\hline $\begin{array}{l}\text { de Rassenfosse } \\
\text { (2015) }\end{array}$ & $\begin{array}{l}\text { The fee elasticity of demand } \\
\text { for international trademarks }\end{array}$ & $\begin{array}{l}\text { Multi-country } \\
\text { analysis }\end{array}$ & 2004-2013 & WIPO \\
\hline $\begin{array}{l}\text { Flikkema et al. } \\
\text { (2015) }\end{array}$ & $\begin{array}{l}\text { The link between trademarks } \\
\text { and innovations, filing } \\
\text { strategies }\end{array}$ & $\begin{array}{l}\text { Benelux } \\
\text { countries }\end{array}$ & 2009 & $\begin{array}{c}\text { OHIM, EPO, } \\
\text { Benelux Office for IP }\end{array}$ \\
\hline $\begin{array}{l}\text { Castaldi } \\
(2016)\end{array}$ & $\begin{array}{l}\text { The relationship between } \\
\text { trademark portfolios and } \\
\text { economic performance }\end{array}$ & $\begin{array}{l}\text { Multi-country } \\
\text { analysis }\end{array}$ & $2005-2012$ & $\begin{array}{l}\text { USPTO, } \\
\text { OHIM }\end{array}$ \\
\hline $\begin{array}{l}\text { Crass et al. } \\
(2016)\end{array}$ & $\begin{array}{l}\text { The effect of investment in } \\
\text { brand equity on firm } \\
\text { financial performance }\end{array}$ & Germany & 2010 & $\begin{array}{c}\text { OHIM, } \\
\text { EPO, DPMA }\end{array}$ \\
\hline $\begin{array}{l}\text { Faurel et al. } \\
(2016)\end{array}$ & $\begin{array}{l}\text { The impact of CEO pay } \\
\text { incentives on new product } \\
\text { development }\end{array}$ & U.S. & $1993-2011$ & USPTO \\
\hline $\begin{array}{l}\text { Heath and Mace } \\
(2017)\end{array}$ & $\begin{array}{l}\text { The effect of trademark } \\
\text { protection on firm profits } \\
\text { and strategy }\end{array}$ & U.S. & $1982-2005$ & USPTO \\
\hline
\end{tabular}

\section{Book chapters}

\begin{tabular}{|c|c|c|c|c|}
\hline $\begin{array}{l}\text { Greenhalgh and Rogers } \\
\text { (2006a) }\end{array}$ & $\begin{array}{l}\text { The market value of } \\
\text { trademarks }\end{array}$ & U.K. & $1996-2000$ & $\begin{array}{l}\text { IPO, } \\
\text { OHIM }\end{array}$ \\
\hline $\begin{array}{l}\text { Griffiths and Webster } \\
(2006)\end{array}$ & $\begin{array}{l}\text { The market value of } \\
\text { trademarks }\end{array}$ & Australia & 1989-2002 & IP Australia \\
\hline $\begin{array}{l}\text { Greenhalgh and Rogers } \\
(2008)\end{array}$ & $\begin{array}{l}\text { Determinants of trademark } \\
\text { deposits }\end{array}$ & U.K. & $1996-2000$ & $\begin{array}{c}\text { Marquesa } \\
\text { Search Systems }\end{array}$ \\
\hline $\begin{array}{l}\text { Duguid et al. } \\
(2010)\end{array}$ & $\begin{array}{l}\text { The role of trademarks in } \\
\text { economic development and } \\
\text { international trade }\end{array}$ & $\begin{array}{l}\text { France, } \\
\text { U.K, U.S. }\end{array}$ & $1870-1970$ & $\begin{array}{c}\text { Various } \\
\text { historical sources }\end{array}$ \\
\hline
\end{tabular}

\begin{tabular}{|c|c|c|c|c|}
\hline $\begin{array}{l}\text { Farooqui et al. } \\
\text { (2011) }\end{array}$ & $\begin{array}{l}\text { Market sector investments } \\
\text { in knowledge capital and } \\
\text { their contribution to growth }\end{array}$ & U.K. & 1990-2008 & $\begin{array}{l}\text { Community } \\
\text { Innovation Survey }\end{array}$ \\
\hline $\begin{array}{l}\text { Greenhalgh et al. } \\
\text { (2011) }\end{array}$ & $\begin{array}{l}\text { A link between trademark } \\
\text { activities and firm } \\
\text { performance }\end{array}$ & U.K. & 2000-2006 & $\begin{array}{l}\text { IPO, } \\
\text { OHIM }\end{array}$ \\
\hline $\begin{array}{l}\text { von Graevenitz et al. } \\
\text { (2012) }\end{array}$ & $\begin{array}{l}\text { The problem of "cluttering" } \\
\text { of trademark registers }\end{array}$ & U.K. & $2000-2007$ & $\begin{array}{c}\text { IPO, } \\
\text { OHIM, WIPO }\end{array}$ \\
\hline $\begin{array}{l}\text { Helmers and Schautschick } \\
\text { (2013) }\end{array}$ & $\begin{array}{l}\text { The use of different types of } \\
\text { intellectual property rights } \\
\text { for the same product }\end{array}$ & U.K. & $2002-2009$ & $\begin{array}{l}\text { IPO, EPO, } \\
\text { OHIM }\end{array}$ \\
\hline $\begin{array}{l}\text { Helmers et al. } \\
\text { (2013) }\end{array}$ & $\begin{array}{l}\text { The relationship between } \\
\text { intellectual property rights } \\
\text { and firm performance }\end{array}$ & U.K. & 2002-2009 & $\begin{array}{l}\text { IPO, EPO, } \\
\text { OHIM }\end{array}$ \\
\hline $\begin{array}{l}\text { WIPO } \\
(2013)\end{array}$ & $\begin{array}{l}\text { The role of trademarks in } \\
\text { protecting brands and brand } \\
\text { strategy }\end{array}$ & $\begin{array}{l}\text { Multi-country } \\
\text { analysis }\end{array}$ & $1974-2011$ & WIPO \\
\hline
\end{tabular}




\begin{tabular}{|c|c|c|c|c|}
\hline \multicolumn{5}{|c|}{ Dataset descriptions } \\
\hline $\begin{array}{l}\text { Graham et al. } \\
\text { (2013) }\end{array}$ & Trademark case files dataset & U.S. & $1870-2012$ & USPTO \\
\hline $\begin{array}{l}\text { Marco et al. } \\
(2014)\end{array}$ & $\begin{array}{l}\text { Trademark assignment } \\
\text { dataset }\end{array}$ & U.S. & $1952-2013$ & USPTO \\
\hline $\begin{array}{l}\text { Dernis et al. } \\
(2015)\end{array}$ & $\begin{array}{l}\text { Intellectual property bundles } \\
\text { of world top } 2,000 \text { corporate } \\
\text { R\&D investors }\end{array}$ & $\begin{array}{l}\text { Multi-country } \\
\text { analysis }\end{array}$ & $2010-2012$ & $\begin{array}{c}\text { EC JRC, } \\
\text { OECD }\end{array}$ \\
\hline
\end{tabular}

